\title{
Intracellular delivery of trehalose renders mesenchymal stromal cells viable and immunomodulatory competent after cryopreservation
}

\author{
Barbara Dovgan • Damijan Miklavčič (i) - Miomir Knežević • Janja Zupan (id) \\ Ariana Barlič (i)
}

Received: 5 November 2020/Accepted: 19 March 2021/Published online: 15 April 2021

(C) The Author(s), under exclusive licence to Springer Nature B.V. 2021

\begin{abstract}
Trehalose is a nontoxic disaccharide and a promising cryoprotection agent for medically applicable cells. In this study, the efficiency of combining trehalose with reversible electroporation for cryopreservation of two types of human mesenchymal stromal cells was investigated: adipose-derived stromal cells, and umbilical-cord-derived stromal cells. Comparable results to standard dimethyl sulfoxide cryopreservation protocols were achieved, even without extensive electroporation parameters and protocol optimization. The presence of high extracellular trehalose resulted in comparable cell viabilities without and with electroporation. According to the determination of trehalose concentrations, $250 \mathrm{mM}$ extracellular trehalose resulting in, $20 \mathrm{mM}$ to $50 \mathrm{mM}$ intracellular trehalose were sufficient for successful
\end{abstract}

B. Dovgan · D. Miklavčič · M. Knežević ·

J. Zupan · A. Barlič

Faculty of Electrical Engineering, University of

Ljubljana, Tržaška 25, 1000 Ljubljana, Slovenia

e-mail: damijan.miklavcic@fe.uni-lj.si

\section{J. Zupan}

e-mail: janja.zupan@ffa.uni-lj.si

B. Dovgan · D. Miklavčič · M. Knežević ·

J. Zupan · A. Barlič

Faculty of Pharmacy, University of Ljubljana, Aškerčeva

7, 1000 Ljubljana, Slovenia

\section{A. Barlič $(\square)$}

Educell Ltd, Prevale 9, 1236 Trzin, Slovenia

e-mail: ariana.barlic@educell.si cryopreservation of cells. With electroporation, higher (i.e. $50 \mathrm{mM}$ to $90 \mathrm{mM}$ ) intracellular trehalose was achieved after cryopreservation, although cell survival was not improved significantly. To evaluate the impact of electroporation and cryopreservation on cells, stress and immune-activation-related gene expression were analyzed. Electroporation and/or cryopreservation resulted in increased SOD2 and HSPA1A expression. Despite the increased stress response, the high upregulation by mesenchymal stromal cells of immunomodulatory genes in the inflammatory environment was not affected. Highest expression was seen for the IDOI and TSG6 genes. In conclusion, cryopreservation of mesenchymal stromal cells in trehalose results in comparable characteristics to their cryopreservation using dimethyl sulfoxide.

Keywords Trehalose - Cryopreservation · Mesenchymal stromal cells · Electroporation . Immunomodulation

\section{Introduction}

Cell-based medicine is becoming increasingly important for modern healthcare. A large number of clinical trials into the use of mesenchymal stromal cells (MSCs) from different tissue sources are ongoing for treatment of various diseases (Kabat et al. 2020), 
including COVID-19 (Golchin et al. 2020). Therefore, it is important to be able to provide high-quality cell products for patients.

Cryopreservation at sub-zero temperatures is the most widely used method for long-term storage of cells and tissues, which allows preservation of their vital functions upon thawing Dulugiac et al. 2015; Marquez-Curtis et al. 2015; Mitchell et al. 2015; Pilbauerová et al. 2018; Ramos et al. 2014; Yong 2015). As the use of cell-based therapies advances, there is thus also the need for safer and more effective cryopreservation protocols for these cell products (Awan et al. 2020; de Luca et al. 2019; Hornberger et al. 2019; Weng and Beauchesne 2020).

Cryopreservation methods and protocols seek to reach low temperatures without causing damage to the cells through formation of ice crystals during freezing. Dimethyl sulfoxide (DMSO) has been the cryoprotectant of choice for most animal cell cryopreservation protocols since the early history of this technology (Awan et al. 2020; Weng and Beauchesne 2020). However, DMSO is highly cytotoxic and is also cardiotoxic, and it has to be removed quickly after cell thawing and before the use of the cells in patients (Baust et al. 2017; Fry et al. 2015).

In certain clinical therapies, a variety of cell products are used directly after thawing (e.g., cord blood, bone marrow transplantations, MSC infusions), and so they are infused without removing the DMSO (Shu et al. 2014). Even at very low concentrations, infusion of DMSO represents an added risk to the patient. The cytotoxicity of DMSO in clinical settings is associated with several side effects, such as nausea, vomiting, diarrhea, hemolysis, rashes, renal failure, hypertension, bradycardia, and pulmonary edema (Weng and Beauchesne 2020).

Various ways to minimize these toxic effects of DMSO have been described. In some cases, proposals have indicated the use of reduced DMSO concentrations, such as from 10 to $5 \%$ (Akkök et al. 2008; Bakken et al. 2003) or 3.5\% (Halle et al. 2001). Alternatively, the complete or partial replacement of DMSO with nontoxic cryoprotectants has been proposed (Awan et al. 2020; Weng and Beauchesne 2020). Several washing steps are needed to remove DMSO from these cell products prior to their infusion into patients. However, additional manipulations of therapeutic products usually result in significant loss of cell numbers (Laroche et al. 2005; Wang et al. 2011).

Current cryopreservation protocols often include fetal bovine serum (FBS) or human blood derivates (e.g., serum, platelet lysate) in addition to DMSO and also their replacement would be advantageous (AlSaqi et al. 2015; Ikebe and Suzuki 2014; MiyagiShiohira et al. 2016). Therefore, it is of great importance for the safety of patients to achieve cell cryopreservation using nontoxic, xeno-free cryoprotectants. Also, these practices need to be standardized across transplantation centers, to harmonize cryopreservation protocols for cell-based therapeutics (Awan et al. 2020; Weng and Beauchesne 2020).

The disaccharide trehalose represents one of the promising nontoxic cryoprotectants. It is found in several organisms that are adapted to extreme conditions, such as low temperatures or dehydrated environments (Brockbank et al. 2010; Crowe and Crowe 2000; Larson et al. 2014). With a view to clinical use, this disaccharide has been used successfully for cryopreservation of different types of human cells, including in particular: platelets, red blood cells and stem blood cells, as well as sperm, oocytes, pancreatic islets, and fetal skin (Awan et al. 2020). Trehalose has also been used in pharmaceutical applications (Patist et al. 2005), such as in ophthalmology (Aragona et al. 2014; Chiambaretta et al. 2017). Currently, several xeno-free and DMSO-free cryopreservation reagents with indications of good manufacturing practice status are available for clinical application (Awan et al. 2020). Whether trehalose is part of these reagents has unfortunately not been disclosed, due to the nondisclosure nature of their compositions.

Different extracellular trehalose concentrations have been reported as providing successful cell cryopreservation (Campbell and Brockbank 2012; Dovgan et al. 2017; Eroglu et al. 2000, 2009; Mutsenko et al. 2019; Shirakashi et al. 2002; Wolkers et al. 2001; Zhou et al. 2010). To achieve successful cell cryopreservation, trehalose has to be present on both sides of the cell membrane; i.e., both extracellularly and intracellularly (Crowe et al. 2005). Various strategies for loading trehalose into mammalian cells have been suggested that enable effective cryopreservation, desiccation, and lyopreservation. Trehalose can be loaded into cells through a number of processes and pathways, as summarized by Stewart and $\mathrm{He}$ (2019). These include phospholipid-phase transition 
induced by thermal or osmotic stress, endocytosis engineered pores and channels, using the trehalose specific transporter TRET1, microinjection, as well as use of various polymers, peptides, liposomes, nanoparticles, and ultrasound.

One possible and relatively simple method for introducing trehalose into cells is electroporation. During electroporation, the permeability of the cell membrane is transiently increased, which can allow trehalose and other membrane-nonpermeable molecules to be loaded into cells (Kotnik et al. 2012, 2019; Rems and Miklavčič 2016). Electroporation is used in clinical settings to introduce small and large molecules into cells, such as chemotherapeutic drugs, to enhance their intracellular accumulation and cytotoxicity. Large molecules like RNA and DNA have also been introduced into cells in this way, for gene therapies (Geboers et al. 2020; Roth et al. 2018). Indeed, electroporation has already been used in cryobiology as a tool for the introduction of impermeable saccharides into various cells (Dovgan et al. 2017; Dymek et al. 2014; Mutsenko et al. 2019; Shayanfan et al. 2013; Zhou et al. 2010).

In the present study, we used reversible electroporation for trehalose loading into human umbilicalcord-derived (UC-MSCs) and human adipose-derived stromal cells (ASCs). The lowest extracellular and intracellular concentrations of trehalose needed to preserve optimal cell viability were determined. In addition, gene expression analysis was performed to examine the stress induced by electroporation and cryopreservation of these cells. The objective of the study was also to determine the effects of cryopreservation with trehalose in terms of the immunomodulatory actions of MSCs.

\section{Materials and methods}

Cell culture

Human adipose tissue was obtained from a single donor scheduled for elective lipoaspiration, following the signing of informed consent and according to the ethical guidelines of the National Medical Ethics Committee (code 21/09/07). The ASCs were isolated from the tissue as described previously (Zuk et al. 2001).
Human UC-MSCs were obtained from a single donor umbilical cord following signing of informed consent and again according to the ethical guidelines of the National Medical Ethics Committee (code 136/02/12). The UC-MSCs were isolated using an explant protocol, as described previously (Pirjali et al. 2013).

All of these cells were cultured in DMEM/F-12 media supplemented with $10 \%$ FBS, $50 \mu \mathrm{g} / \mathrm{mL}$ gentamicin, (all from Gibco) and $1 \mathrm{ng} / \mathrm{mL}$ basic fibroblast growth factor (Peprotech), in a humidified incubator at $37{ }^{\circ} \mathrm{C}$ and $5 \% \mathrm{CO}_{2}$. The media were changed twice per week. At about $95 \%$ confluency, the cells were detached with $0.05 \%$ trypsin-EDTA (Sigma Aldrich) and replated at 3000 cells $/ \mathrm{cm}^{2}$. For the experiments, cells of the third to sixth passage were used. Identification of the cells was performed through their expression of surface markers (i.e., CD73, CD90, CD105) using flow cytometry, and also according to their osteogenic and adipogenic differentiation. The cells used expressed these surface markers and could undergo osteogenic and adipogenic differentiation (data not shown).

Intracellular trehalose determination

Determination of intracellular trehalose concentrations was performed immediately following electroporation and for different incubation temperatures (4, 25, $37{ }^{\circ} \mathrm{C}$; $30 \mathrm{~min}$; for resealing of cell membranes) before cryopreservation, and as an immediate assay after cryopreservation. This was carried out for both nonelectroporated cells and electroporated cells in the presence of $250 \mathrm{mM}$ trehalose. Nontreated cells (i.e., no trehalose and no electroporation) were used as the control before electroporation. Nontreated cells cryopreserved with DMSO were used as the control after cryopreservation.

\section{Electroporation}

Cell suspensions were prepared at a cell density of $1 \times 10^{6}$ cells $/ 100 \mu \mathrm{L}$ in low-conduction electroporation buffer $\left(10 \mathrm{mM} \mathrm{K} \mathrm{K}_{2} \mathrm{HPO}_{4}\right.$ [Merck], $10 \mathrm{mM}$ $\mathrm{KH}_{2} \mathrm{PO}_{4}, 1 \mathrm{mM} \mathrm{MgCl} 2$ [Sigma Aldrich]) that generally contained $250 \mathrm{mM}$ trehalose (also, 0, 10, 50, 100, $250 \mathrm{mM}$ trehalose for cell viability procedures). Buffer osmolalities for $0,10,50$, and $100 \mathrm{mM}$ trehalose were adjusted to $300 \mathrm{mOsm}$ with the 
addition of $\mathrm{NaCl}$ (Sigma Aldrich). Cell suspensions were transferred to 2-mm electroporation cuvettes (Peqlab), and 8 pulses of $100 \mu$ s at $1 \mathrm{~Hz}$ and $300 \mathrm{~V}$ (electric field, $1.5 \mathrm{kV} / \mathrm{cm}$ ) were delivered by the electroporator (BTX Gemini). The nonelectroporated cells were treated in the same way in all aspects (except they were not placed in the cuvettes). After this 2-min incubation at room temperature for the control (nonelectroporated) and electroporated cells, $95 \mu \mathrm{L}$ cell suspension was transferred to a cryovial. For the intracellular trehalose determination procedures, the cells then either had no incubation or were incubated for an additional $30 \mathrm{~min}$ at different temperatures $\left(4,25,37{ }^{\circ} \mathrm{C}\right)$, to allow the cell membranes to reseal. For the viability and gene expression procedures, only the incubation at $37{ }^{\circ} \mathrm{C}$ was used.

For intracellular trehalose determination, half of each sample was analyzed before cryopreservation, and the other half was cryopreserved and analyzed after cryopreservation. Nontreated cells were resuspended in FBS and immediately cryopreserved using the DMSO protocol.

\section{Cryopreservation}

The standard cryopreservation medium was $10 \%$ (v/v) DMSO in $90 \%(\mathrm{v} / \mathrm{v})$ FBS (henceforth referred to as DMSO). The other cryopreservation media involved addition of trehalose $(0,10,50,100,250 \mathrm{mM})$ to the electroporation buffer, with cryopreservation either directly after the $30 \mathrm{~min}$ incubation or after electroporation (as described above). For the DMSO procedures, the same cell numbers were harvested in microcentrifuge tubes and centrifuged for $5 \mathrm{~min}$ at $500 \times \mathrm{g}$. After removal of the supernatant, the precooled $\left(2-8 \quad{ }^{\circ} \mathrm{C}\right)$ cryopreservation medium (volume, $100 \mu \mathrm{L}$ ) was slowly added drop by drop to the cell pellet and mixed. These cell suspensions were immediately transferred into cryovials and cryopreserved. All of the samples in cryovials intended for cryopreservation (i.e., nonelectroporated, electroporated, DMSO control) were frozen in a freezing container (Mr. Frosty; Thermo Fisher Scientific), with cooling at around $-1{ }^{\circ} \mathrm{C} / \mathrm{min}$, to achieve $-80{ }^{\circ} \mathrm{C}$. The next day, the cells were transferred into liquid nitrogen containers $\left(-196{ }^{\circ} \mathrm{C}\right)$ for at least 1 week.

Immediately after removal of the cryovials from the liquid nitrogen, the thawing was performed by addition of preheated $\left(37{ }^{\circ} \mathrm{C}\right) 100 \mathrm{mM}$ trehalose or $20 \%$
FBS in DMEM/F-12 into the cryovials that contained the frozen cells for the trehalose and DMSO protocols, respectively. This was designed to accelerate the thawing process and to prevent osmotic imbalance. The cryoprotectant was diluted 7-10-fold (v/v) with cell culture medium, centrifuged immediately, and removed.

For intracellular trehalose determination, all of the cell samples were collected in microcentrifuge tubes $\left(5-8 \times 10^{5}\right.$ cells) before and after cryopreservation. The cells were washed three times with phosphatebuffered saline (Gibco), to remove any extracellular trehalose. After the last wash, to release all of the intracellular trehalose, the cells were resuspended in $135 \mathrm{mM}$ citrate buffer (Sigma Aldrich) at pH 5.7, and incubated at $95{ }^{\circ} \mathrm{C}$ for $15 \mathrm{~min}$. To cleave the trehalose into two glucose molecules, the samples were incubated with the enzyme trehalase (final concentration, $0.2 \mathrm{U} / \mathrm{mL}$; Sigma Aldrich) for 18-20 h. The resulting glucose was then assayed using colorimetric glucose assay kits (GAGO-20; Sigma Aldrich), according to the manufacturer instructions. Absorbance at $540 \mathrm{~nm}$ was measured using a multiplate reader (Chameleon; Hidex). For background correction, the absorbance at $660 \mathrm{~nm}$ was subtracted from the measurements.

To calibrate the intracellular trehalose concentrations, the glucose standard curve was first prepared by plotting absorbance versus glucose concentration $(\mathrm{mM})$. Using the standard curve equation, the glucose concentrations in the samples were obtained. These glucose concentrations were then corrected for the dilution factor and divided by 2 , as one trehalose molecule was cleaved into two glucose molecules by trehalase. Intracellular concentrations were calculated according to the total cell volume.

For cell volume calculations, the average cell diameter of $17 \mu \mathrm{m}$ was used for the ASCs and $15 \mu \mathrm{m}$ for the UC-MSCs, as determined using an automated cell counter (Countess; Invitrogen). The total cell volumes were then calculated according to the volume of a sphere, and multiplied by the total cell numbers. Our cell size measurements for the MSCs were similar to those obtained previously $(15 \mu \mathrm{m})$ (Oliver et al. 2004; Ge et al. 2014).

The intracellular trehalose concentrations were then determined by multiplying the volume of the trehalose solution and the measured trehalose (i.e., glucose/2) concentration in the solution, divided by 
the total cell volume, which was multiplied by a factor of 0.5 , as the free cell volume was estimated to be $50 \%$ of the total cell volume (Oliver et al. 2004; Wolkers et al. 2001). However, these data must remain as approximations, as small variations in cell size or cell numbers can have large effects on cell volume, and consequently on intracellular trehalose concentrations.

To ensure that all of the trehalose was converted into glucose, $100 \mathrm{mM}$ and $250 \mathrm{mM}$ trehalose in citrate buffer were prepared and subjected to cleavage by the trehalase enzyme using the same protocol as for the samples. Controls without trehalose before and after cryopreservation were performed (i.e., nontreated cells, or cells cryopreserved with DMSO), where no intracellular trehalose should be detected. The data were generated as single measurements in three technical replicates.

\section{Cell viability}

Cell viability was assessed using two different assays: Trypan blue dye exclusion (referred to as the assays for 'cell survival') and MTT assays (referred to as the assays for 'cell proliferation'). Cell viability assays were performed before and after cryopreservation, for the nonelectroporated cells in the presence of different trehalose concentrations $(0-250 \mathrm{mM})$ and for the electroporated cells in the presence of the same trehalose concentrations. Nontreated cells were used as the control before cryopreservation. For the control after cryopreservation, nontreated cells were cryopreserved with DMSO. Electroporation and cryopreservation were performed as described above.

To determine cell survival, the cell suspensions were diluted $1: 1$ with $0.4 \%$ Trypan blue (Fluka), and the staining of cells was examined under an inverted light microscope (Eclipse TS100, Nikon). Cell survival was expressed as the proportion (\%) of viable unstained cells relative to the total number of cells counted, using a hemocytometer. Cell counting was carried out in duplicate, with calculation of the means. The experiments were performed as at least three independent repetitions.

Cell proliferation was determined using a colorimetric MTT assay, as described by Mossman (1983), with some modifications. Briefly, the cells were seeded in 96-well plates at 50,000 cells/well, with the addition of cell culture medium (DMEM/F-12,
$10 \%$ FBS, $50 \mu \mathrm{g} / \mathrm{mL}$ gentamicin). Following an overnight incubation at $37{ }^{\circ} \mathrm{C}$ and $5 \% \mathrm{CO}_{2}$, the medium was removed and replaced with MTT solution (final MTT concentration $0.5 \mathrm{mg} / \mathrm{mL}$; Sigma Aldrich). After at least $6 \mathrm{~h}$ of incubation at $37{ }^{\circ} \mathrm{C}$, a purple-colored formazan product developed. The MTT solution was removed, and the formazan crystals were dissolved in acidified isopropanol $(0.04 \mathrm{M} \mathrm{HCl}$ in isopropanol; both from Sigma Aldrich). The absorbance at $570 \mathrm{~nm}$ was then measured using a microplate reader (Chameleon, Hidex). For background correction, the absorbance at $660 \mathrm{~nm}$ was subtracted from the measurements, according to the manufacturer instructions. Cell proliferation (\%) was calculated by dividing the absorbance values obtained in the test samples by the absorbance values obtained in the nontreated cells (i.e., before cryopreservation) or the DMSO samples (i.e., after cryopreservation), multiplied by 100 . The experiments were performed as at least three independent repetitions.

Gene expression analysis: stress response

Gene expression analysis for assessment of stress responses was performed at different times $(0,3,6$, $12 \mathrm{~h}$ ) both before and after cryopreservation, for the nonelectroporated cells with $250 \mathrm{mM}$ trehalose and the electroporated cells with $250 \mathrm{mM}$ trehalose. The nontreated cells (i.e., no trehalose, no electroporation) were used as the control before cryopreservation. The nontreated cells cryopreserved in DMSO were used as the control after cryopreservation. Electroporation and cryopreservation were performed as described in the previous sections.

After electroporation (or no electroporation), half of the cells was removed immediately $(0 \mathrm{~h}$, which includes the $30 \mathrm{~min}$ for membrane resealing) or seeded for 3, 6, and $12 \mathrm{~h}$ in cell culture medium; the other half of the cells was cryopreserved. Cryopreservation was performed in the corresponding cryopreservation medium. After thawing, the cells were again sampled immediately $(0 \mathrm{~h})$ or seeded for 3,6 , and $12 \mathrm{~h}$ in cell culture medium. The same seeding protocol was applied to the control cell samples before and after cryopreservation.

Sampling and total RNA isolation were performed using mammalian total RNA miniprep kits (GenElute; Sigma), according to the manufacturer protocol. The quantities of the isolated RNA were measured using 
RNA assay kits (Quant-iT RiboGreen; Life Technologies). For $500 \mathrm{ng}$ of each isolated RNA sample, cDNA was generated using High-capacity cDNA reverse transcription kits (Life Technologies), which was then stored at $-20{ }^{\circ} \mathrm{C}$. Quantitative polymerase chain reaction (qPCR) was performed in 384-well optical plates in $10 \mu \mathrm{L}$ reaction volumes, using a real-time PCR system (7900HT Fast; Applied Biosystems). TaqMan Gene Expression Master Mix and TaqMan Gene Expression Assays were used (Applied Biosystems). The assay IDs were: Hs00608023_m1, B-cell lymphoma 2 gene (BCL2); Hs00359163_s1, heat shock $70 \mathrm{kDa}$ protein 1 (HSP701A); Hs00155436_m1, heat shock protein beta-2 (HSPB2); Hs01034249_m1, tumor protein p53 (TP53); Hs00167309_m1, superoxide dismutase (SOD2); and Hs00187842_m1, $\beta 2$ microglobulin $(B 2 M)$. The expression of two reference genes was validated, and $B 2 M$ was chosen for the normalization, due to its constant expression under all of the experimental conditions. Reactions were performed as technical duplicates. The data analysis was performed using a sequence detection system (7900HT version 2.4; ABI) and was based on the $2^{-\Delta \Delta \mathrm{Cq}}$ formula (ABI PRISM 7700 Sequence Detection System User Bulletin \#2). To calculate the fold-changes in gene expression, nontreated samples before cryopreservation (at $\mathrm{t}=0 \mathrm{~h}$ ) were used as the calibrator. The relative quantities (RQ) calculated are presented as $\log _{2}(R Q)$. These are presented to also show down-regulation of some of the genes.

Gene expression analysis: MSC activation assay

The MSCs were activated with the cytokines interferon (IFN $\gamma$ ) plus tumor necrosis factor (TNF $\alpha$ ) before and after cryopreservation. Before cryopreservation, only the nontreated cells were activated with the cytokines. After cryopreservation, nontreated cells cryopreserved using DMSO, nonelectroporated cells with $250 \mathrm{mM}$ trehalose, and electroporated cells with $250 \mathrm{mM}$ trehalose were activated. Electroporation and cryopreservation were performed as described in the previous section.

For this activation assay, cells were seeded at $5 \times 10^{5}$ cells per well in 6-well plates for each parameter (nontreated cells, DMSO, with $250 \mathrm{mM}$ trehalose, without and with electroporation) in serumcontaining medium (DMEM/F-12, 10\% FBS), overnight at $37{ }^{\circ} \mathrm{C}$ and $5 \% \mathrm{CO}_{2}$. The next day, the medium was changed for either nonactivating medium (DMEM/F-12 alone) or activating medium (DMEM/ F-12, $1 \mathrm{ng} / \mathrm{mL}$ IFN $\gamma, 1 \mathrm{ng} / \mathrm{mL}$ TNF $\alpha$ [both from Peprotech]). The cells were stimulated for $24 \mathrm{~h}$ at $37{ }^{\circ} \mathrm{C}$ and $5 \% \quad \mathrm{CO}_{2}$, and then sampled for RNA isolation.

Total RNA was extracted from the cells using total RNA kits (peqGOLD; VWR International). The RNA concentrations were determined using a microvolume UV-Vis spectrophotometer (NanoDrop One/OneC; Thermo Fisher Scientific). Samples of cDNA were synthesized from $125 \mathrm{ng}$ to $500 \mathrm{ng}$ of RNA, depending on the individual RNA concentrations, using highcapacity cDNA reverse transcription kits (Thermo Fisher Scientific). qPCR was performed using $5 \times$ HOT FIREPol EvaGreen qPCR Supermix (Solis BioDyne), according to the manufacturer protocol. The genes analyzed were: indoleamine-pyrrole 2,3dioxygenase (IDO1), tumor necrosis factor alphainduced protein 6 (TSG6), interleukin 10 (ILIO), tumor necrosis factor $\alpha$ (TNFA), interleukin 6 (IL6), and transforming growth factor $\beta 1$ (TGFB1). GAPDH was chosen as the reference gene.

The primers (Macrogen, Sigma-Aldrich) used were either self-designed (IDO1-F: TGTCTGGCTGGAA AGGCAAC; IDO1-R: CTGAAAGACGCTGCTTT GGC; IL10-F: GTGATGCCCCAAGCTGAGA; IL10-R: CACGGCCTTGCTCTTGTTTT; TNFA-F: TGGCCCAGGCAGTCAGATCA; TNFA-R: GGCG GTTCAGCCACTGGAGC; IL6-F: GGCACTGGCA GAAAACAACC; IL6-R: GCAAGTCTCCTCATTGAATCC; TGFB1-F: TGGACACCAACTATTGCT TCA; TGFB1-R: GGCAGAAGTTGGCATGGTAG) or were from previous studies (TSG6, Kui et al. 2017; GAPDH, Vandesompele et al. 2002).

All of the qPCR experiments were performed in triplicate using a PCR system (LightCycler 480 Instrument II; Roche). The gene expression data were obtained using a standard curve and the second derivative maximum method (LightCycler 480 software, v. 1.5.0). All of the data were normalized to GAPDH expression. To obtain the RQ values (foldchanges), the expression of stimulated samples was normalized to the nonstimulated counterparts. The data are presented as $\log _{2}(R Q)$, to also show downregulation of some of the genes. 
Statistical analysis

The data are presented as means \pm standard error (SE) of the mean. The statistical significance of the differences between the groups was evaluated using one-way, parametric ANOVA tests. Statistical analysis was performed using GraphPad Prism, version 6.01 (GraphPad Software, Inc).

For gene expression analyses (fold-change), logtransformation was applied to all of the gene expression data in graphic presentation, to approach normal data distribution.

\section{Results}

Intracellular trehalose determination

We initially determined the intracellular trehalose concentrations for the cells (ASCs; UC-MSCs) that were or were not electroporated with $250 \mathrm{mM}$ extracellular trehalose, before and after their cryopreservation (Fig. 1).

Before cryopreservation, the cells were incubated with $250 \mathrm{mM}$ extracellular trehalose and assayed either immediately after the electroporation ( $2 \mathrm{~min}$ at room temperature) or after the post-electroporation cell resealing at 4,25 and $37{ }^{\circ} \mathrm{C}$ (30 min). Significant differences in intracellular trehalose concentrations were seen comparing the nonelectroporated and electroporated cells before cryopreservation. In the nonelectroporated cells some trehalose entry was seen, but the intracellular concentrations remained $<10$ $\mathrm{mM}$ for both cell types (Fig. 1a, c). In the electroporated cells, the intracellular concentrations for the ASCs and UC-MSCs were significantly increased to around $50 \mathrm{mM}$ and $40 \mathrm{mM}$ trehalose, respectively, across all of the cell-resealing conditions (Fig. 1a, c).

After cryopreservation, the intracellular concentrations in the nonelectroporated cells and nonincubated cells increased to around $20 \mathrm{mM}$ trehalose for both the ASCs and UC-MSCs (Fig. 1b, d). By increasing the cell membrane resealing temperature, the intracellular trehalose concentrations for the nonelectroporated ASCs and UC-MSCs were significantly increased, with the highest seen for cell membrane resealing at $37{ }^{\circ} \mathrm{C}$, as $37.3 \pm 2.3 \mathrm{mM}$ and $54.0 \pm 1.8 \mathrm{mM}$, respectively. In the electroporated cells, the intracellular trehalose concentrations were also increased in comparison to the cells before cryopreservation, except at $4{ }^{\circ} \mathrm{C}$, where the intracellular trehalose remained similar after cryopreservation, for both cell types (Fig. 1b, d). For the nonincubated electroporated cells after cryopreservation, the intracellular trehalose concentration increased to $56.7 \pm 2.3 \mathrm{mM}$ and $74.4 \pm 2.3 \mathrm{mM}$ in the ASCs and UC-MSCs, respectively. For the electroporated cells membrane resealed at 25 and $37{ }^{\circ} \mathrm{C}$, the increases were similar, reaching the highest for $37{ }^{\circ} \mathrm{C}$ of $65.7 \pm 2.1 \mathrm{mM}$ and $87.3 \pm 0.6 \mathrm{mM}$ in the ASCs and UC-MSCs, respectively (Fig. 1b, d). Therefore, across all of the tested conditions before cryopreservation, the incubation for cell membrane resealing and the membrane resealing temperature generally had no significant impact upon trehalose uptake, except at $4{ }^{\circ} \mathrm{C}$ after cryopreservation and electroporation at which intracellular trehalose was significantly lower. There are also indications of increased trehalose uptake with increased cell membrane resealing temperature for the nonelectroporated ASCs and UC-MSCs after cryopreservation. Therefore, to ensure all of the trehalose had been converted to glucose in these assays, $100 \mathrm{mM}$ and $250 \mathrm{mM}$ trehalose were prepared and subjected to cleavage by the enzyme trehalase. The calculation of the trehalose concentration for the $100 \mathrm{mM}$ trehalose solution was $108 \mathrm{mM}$ (indicating full enzymatic cleavage), although for the $250 \mathrm{mM}$ trehalose solution the calculated concentration indicated potential incomplete enzymatic cleavage, at 202 $\mathrm{mM}$. However, as all of the intracellular trehalose concentrations assayed here were $<100 \mathrm{mM}$ (maximum, $87.3 \mathrm{mM}$ for UC-MSCs), which indicates that all of the trehalose in these samples was converted to glucose. Further, considering potential interference in this assay by endogenous glucose, in the control cells that were not exposed to extracellular trehalose or electroporation, both without and with cryopreservation with DMSO, the intracellular glucose concentration was about $1 \mathrm{mM}$ for both the ASCs and UCMSCs.

\section{Cell viability}

The cell viability in terms of dependence on exposure to increasing extracellular trehalose concentrations was determined before and after cryopreservation. Cell survival (\%) was determined using the Trypan 

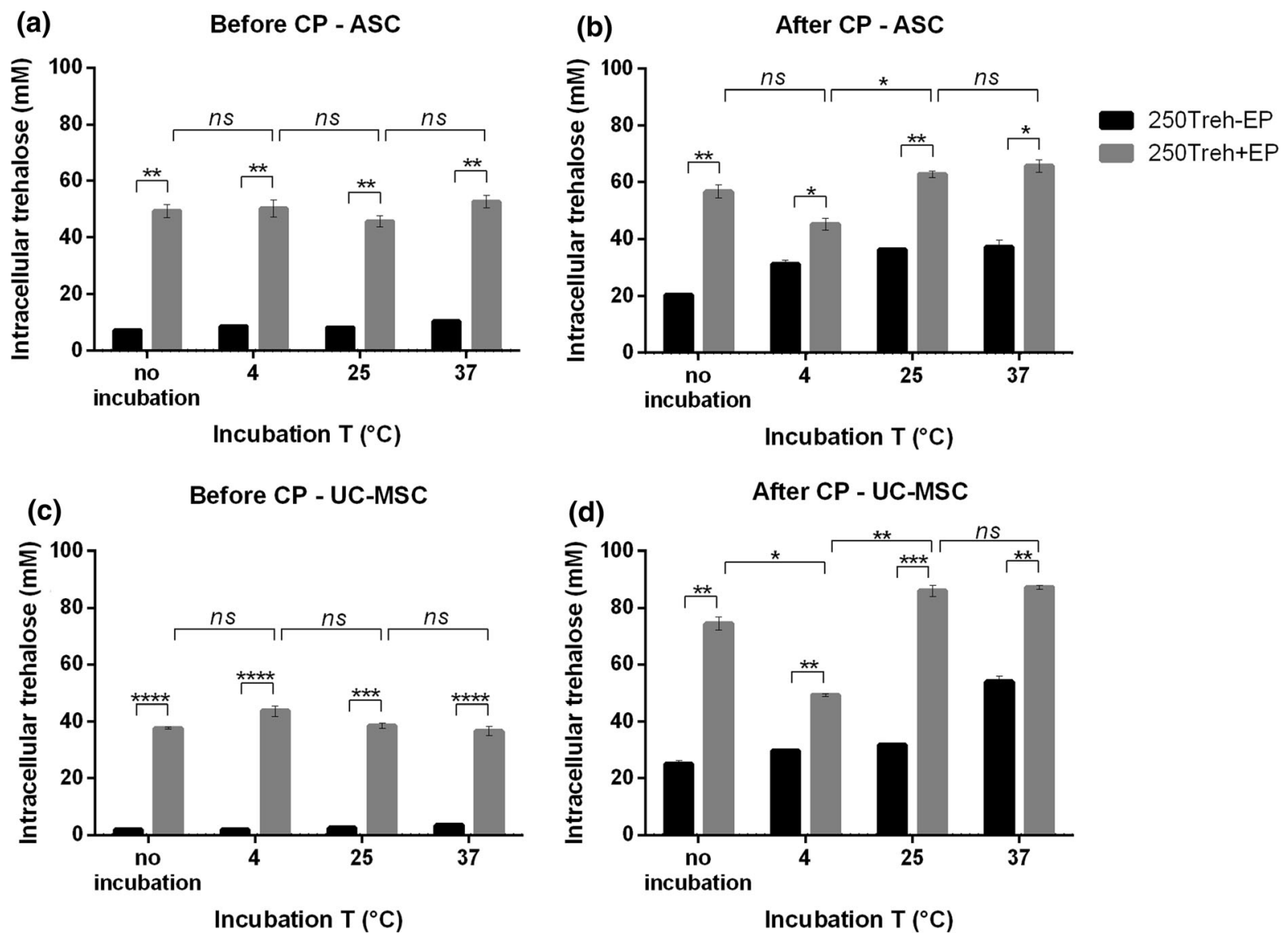

Fig. 1 Determination of intracellular trehalose concentrations of human adipose-derived stromal cells (ASC) (a, b) and human umbilical-cord-derived mesenchymal stromal cells (UC-MSC) (c, d). Before (a, c) and after (b, d) cryopreservation (CP), the cells were incubated with $250 \mathrm{mM}$ trehalose without (250Treh$\mathrm{EP})$ and with (250Treh + EP) electroporation, with incubations

blue exclusion method (Fig. 2), and cell proliferation (\%) with the MTT assay (Fig. 3).

As shown in Fig. 2, compared to nontreated cells, before cryopreservation there was no dependence on trehalose concentration for cell survival for the nonelectroporated and electroporated cells, for both cell types (Fig. 2a, c). However, after cryopreservation, strong trehalose concentration dependence for cell survival was seen for both cell types, whereby the increasing trehalose concentrations promoted increasing cell survival (Fig. 2b, d). At $10 \mathrm{mM}$ extracellular trehalose, post-cryopreservation cell survival was similar to that for cells cryopreserved without trehalose (Fig. 2 and $0 \mathrm{mM}$ ) and without DMSO. At 50 $\mathrm{mM}$ extracellular trehalose, around $20 \%$ of both cell types survived cryopreservation, while at $100 \mathrm{mM}$

at different temperatures (as indicated). The cells with no incubation were processed immediately for intracellular trehalose. Data are means \pm standard error of three technical replicates. $\quad * p<0.05 ; \quad * * p<0.01 ; \quad * * * p<0.001$; $* * * * p<0.0001 ; n s$, not significant (one-way parametric ANOVA test)

trehalose, this was increased to $40-50 \%$ survival. However, at $250 \mathrm{mM}$ extracellular trehalose, cell survival with electroporation was $72.0 \% \pm 3.3 \%$ for ASCs, and $83.0 \% \pm 2.4 \%$ for UC-MSCs, with comparable survival to DMSO cryopreservation, at $75.9 \%$ \pm 2.8 and $81.4 \% \pm 1.1 \%$, respectively. The survival differences between the nonelectroporated and electroporated cells after cryopreservation were small and not significant, reaching about a further $10 \%$ cell survival at $250 \mathrm{mM}$ trehalose.

Similar concentration dependent data were obtained for the cell proliferation assays, both before and after cryopreservation, and without and with electroporation (Fig. 3). Indeed, in $250 \mathrm{mM}$ extracellular trehalose, the cell proliferation for the UC-MSCs was even greater than the DMSO cryopreservation 
(a)
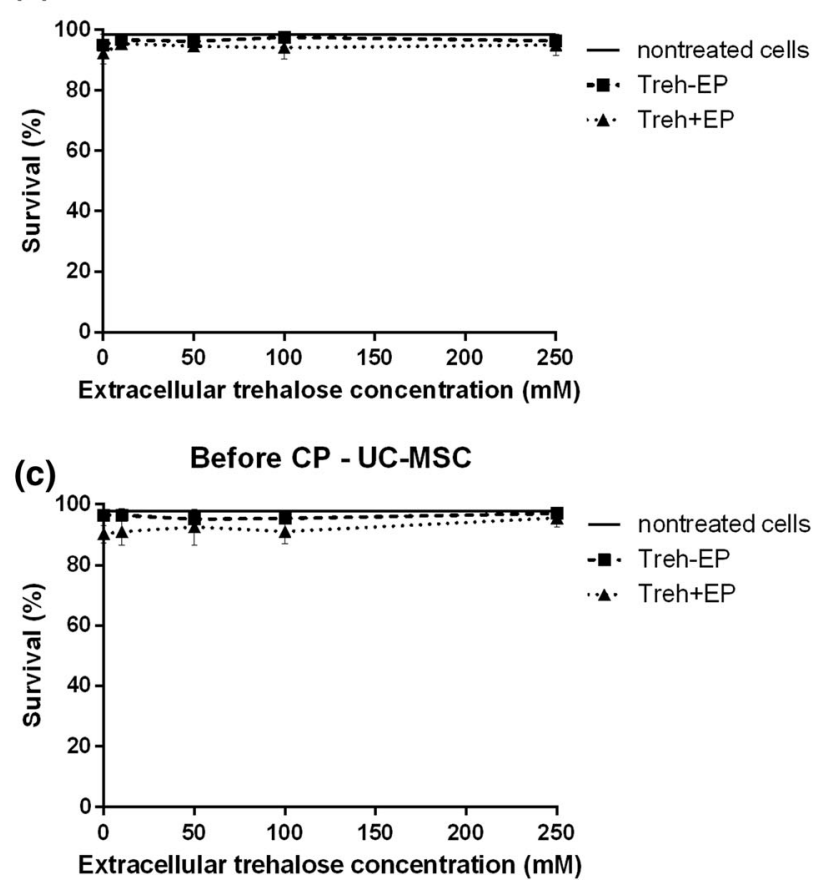

Fig. 2 Cell survival of human adipose-derived stromal cells (ASC) (a, b) and human umbilical-cord-derived mesenchymal stromal cells (UC-MSC) (c, d). Before (a, c) and after (b, d) cryopreservation $(\mathrm{CP})$, cell survival was determined as a function of extracellular trehalose concentration, including

control (Fig. 3d), although no significant differences were seen across these different cryopreservation protocols demonstrating trehalose comparable to DMSO cryopreservation protocol.

Gene expression analysis - stress response

To determine the effects of $250 \mathrm{mM}$ trehalose, electroporation and cryopreservation on gene expression over time $(0,3,6,12 \mathrm{~h})$, the data were normalized to the nontreated cells at $\mathrm{t}=0 \mathrm{~h}$. Initially, expression of various stress-related genes was compared: SOD2, TP53, BCL2, and two genes from the heat shock protein family, HSPB2 and HSPAIA (Fig. 4). The changes in the expression of TP53, HSPB2, and BCL2 were not biologically significant under any of these conditions for both ASCs and UC-MSCs (Fig. 4c-f, i, j). This was based on the biological relevance of the difference between nontreated and treated samples for a calculated fold-change $\geq 4$, which equates to $\log _{2}(\mathrm{RQ})$ fold-change $\geq 2$ for the logarithmic scale.
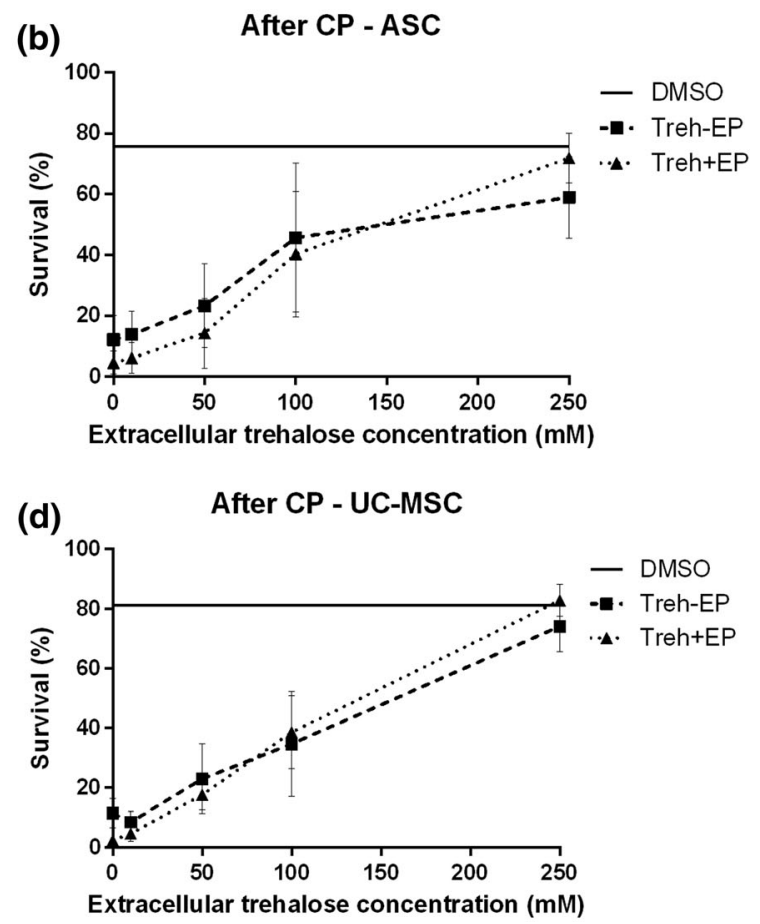

nontreated and DMSO-processed cells, and without (Treh-EP) and with (Treh + EP) electroporation. Cell survival was determined according to the Trypan blue assay. Data are means \pm standard error of at least three independent experiments

For better graphical presentation, the calculated foldchanges were $\log _{2}$ transformed in Figs. 4 and 5.

For SOD2 expression, before cryopreservation, 250 $\mathrm{mM}$ trehalose resulted in increased expression for the electroporated ASCs (5-fold, 7-fold, 9-fold at $3 \mathrm{~h}, 6 \mathrm{~h}$, $12 \mathrm{~h}$, respectively). However, at $3 \mathrm{~h}$ after cryopreservation, the expression of SOD2 was highly upregulated both without and with electroporation. By $12 \mathrm{~h}$, the expression of SOD2 in the electroporated ASCs was 17-fold that of the DMSO ASCs, while in the nonelectroporated ASCs this increase was about 8 -fold. Indeed, in general, the expression of SOD2 was higher after cryopreservation of the ASCs (Fig. 4a). In the UC-MSCs, similar trends were seen, whereby before cryopreservation, $250 \mathrm{mM}$ trehalose promoted up-regulation of $S O D 2$ expression in the electroporated UC-MSCs of 4-fold, 6-fold, and 7-fold at $3 \mathrm{~h}$, $6 \mathrm{~h}$, and $12 \mathrm{~h}$, respectively. In nonelectroporated UCMSCs, the changes in SOD2 expression were not significant. After cryopreservation, SOD2 expression was up-regulated in both the nonelectroporated and 
electroporated UC-MSCs. Then, $12 \mathrm{~h}$ after cryopreservation, the expression of SOD2 remained upregulated 14-fold for the electroporated UC-MSCs and 5-fold for the nonelectroporated UC-MSCs (Fig. 4b). For both of the cell types, the expression of SOD2 increased with time in the electroporated cells, while it was decreased with the nonelectroporated cells (Fig. 4a, b).

Expression of the heat shock protein gene HSPA1A was slightly increased in the electroporated ASCs at $12 \mathrm{~h}$ without cryopreservation (Fig. 4 ). On the other hand, after cryopreservation, expression of HSPA1A was up-regulated after $3 \mathrm{~h}$ in all of the ASCs (Fig. 4g). Interestingly, expression of HSPAIA was consistently higher in the nonelectroporated ASCs (at 4-fold, 29-fold, 58-fold, 35-fold at $0 \mathrm{~h}, 3 \mathrm{~h}, 6 \mathrm{~h}, 12 \mathrm{~h}$, respectively) compared to the electroporated ASCs (at 3-fold, 8-fold, 12-fold, 14-fold at $0 \mathrm{~h}, 3 \mathrm{~h}, 6 \mathrm{~h}$, $12 \mathrm{~h}$, respectively) (Fig. 4g). In UC-MSCs, changes in HSPA1A were only seen at $12 \mathrm{~h}$, both before and after
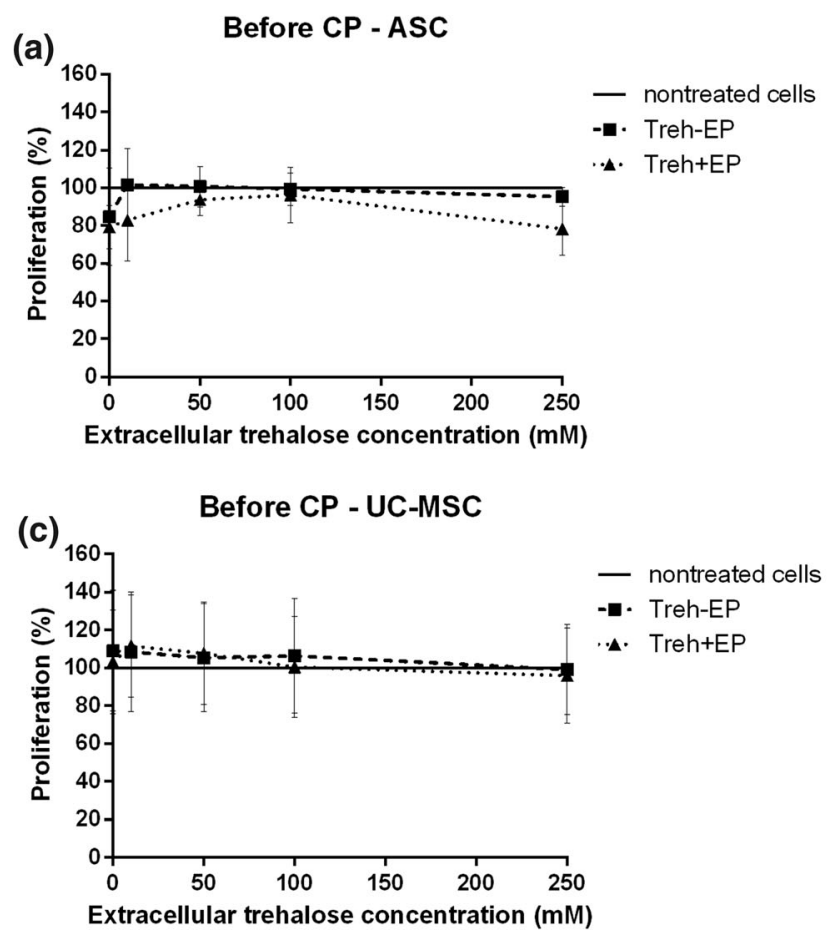

Fig. 3 Cell proliferation of human adipose-derived stromal cells (ASC) (a, b) and human umbilical-cord-derived mesenchymal stromal cells (UC-MSC) (c, d). Cell proliferation was determined before $(\mathbf{a}, \mathbf{c})$ and after $(\mathbf{b}, \mathbf{d})$ cryopreservation $(\mathrm{CP})$, as a function of extracellular trehalose concentration, including
Fig. 4 Expression of the SOD2 (a, b), TP53 (c, d), HSPB2 (e, f), $\operatorname{HSPA1A}(\mathbf{g}, \mathbf{h})$, and BCL2 (i, j) stress-related genes by human adipose-derived stromal cells (ASC) $(\mathbf{a}, \mathbf{c}, \mathbf{e}, \mathbf{g}, \mathbf{i})$ and human umbilical-cord-derived mesenchymal stromal cells (UC-MSC) $(\mathbf{b}, \mathbf{d}, \mathbf{f}, \mathbf{h}, \mathbf{j})$. Gene expression was determined before and after cryopreservation (as indicated) at different times (as indicated), including nontreated and DMSO-processed cells, and with 250 $\mathrm{mM}$ trehalose without (250Treh-EP) and with $(250$ Treh + EP) electroporation. Expression data are means of technical duplicates, as normalized to nontreated (no cryopreservation, no electroporation) cells at $\mathrm{t}=0 \mathrm{~h}$. Differences between treated and nontreated samples can be considered biologically relevant for linear fold-changes $\geq 4$ (i.e., $\log _{2}(R Q) \geq 2$ for the logarithmic scale). RQ, relative quantity (see Methods)

cryopreservation, with slightly higher expression after cryopreservation (Fig. 4h).

Gene expression analysis: MSC activation assay

To determine whether the electroporation- and cryopreservation-induced stress affects the functional properties of these cells, we analyzed nonactivated MSCs
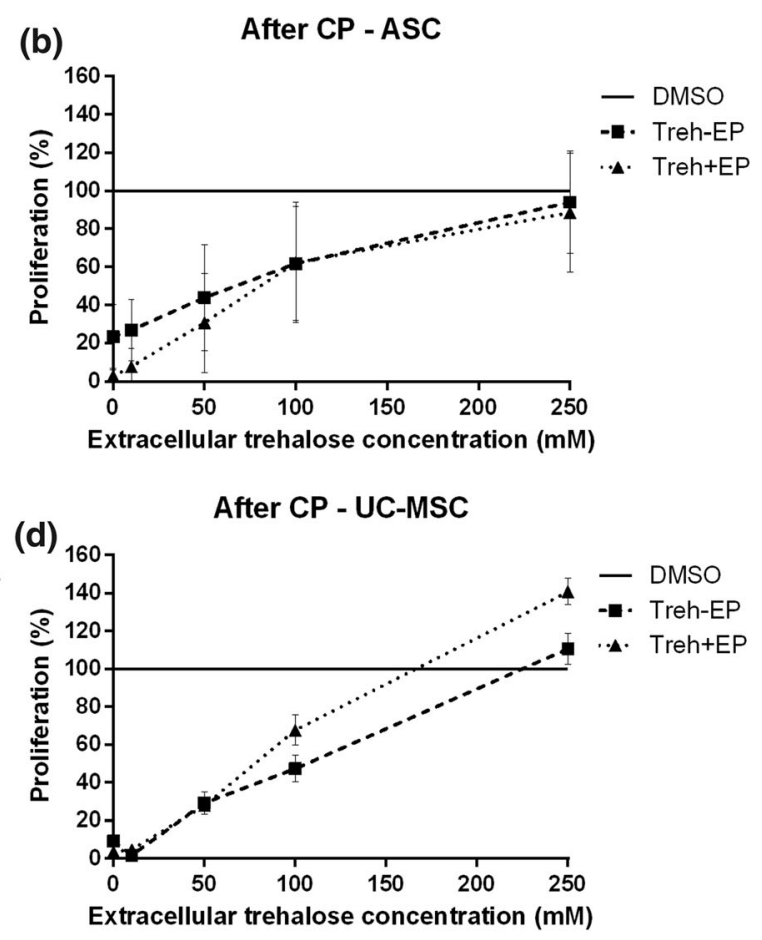

nontreated and DMSO-processed cells, and without (Treh-EP) and with (Treh + EP) electroporation. Cell proliferation was determined according to the MTT assay. Data are means $\pm \mathrm{s}-$ tandard error of at least three independent experiments 


\section{ASC}
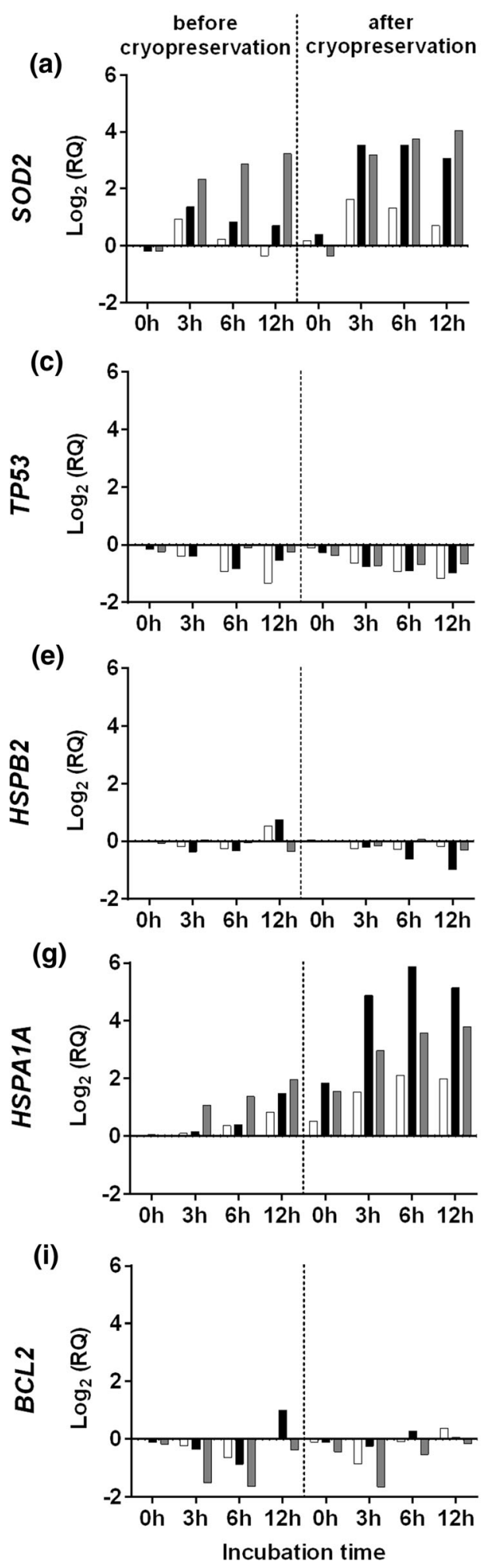

\section{UC-MSC}

(b) cryopreservation cryopreservation

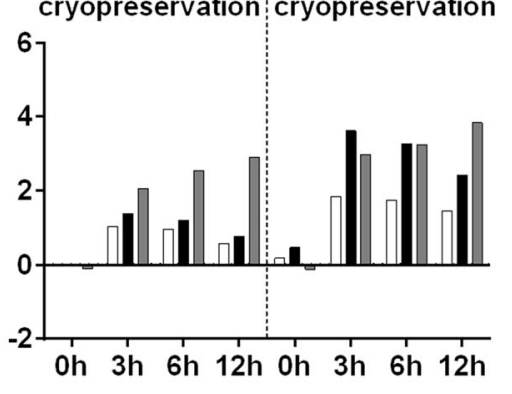

(d)

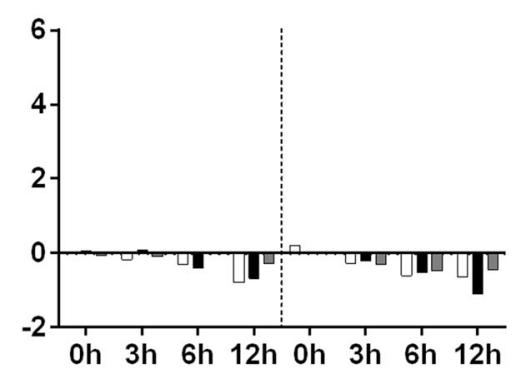

(f)

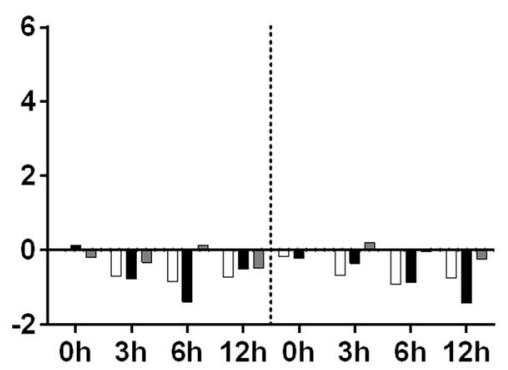

(h)

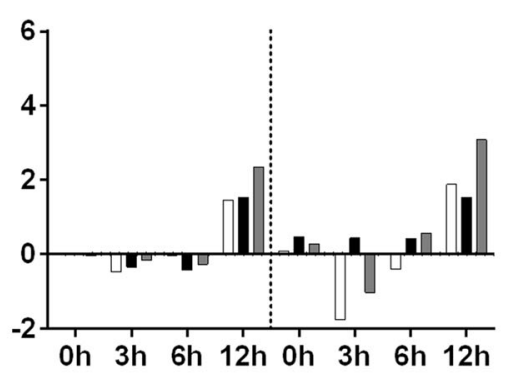

(j)

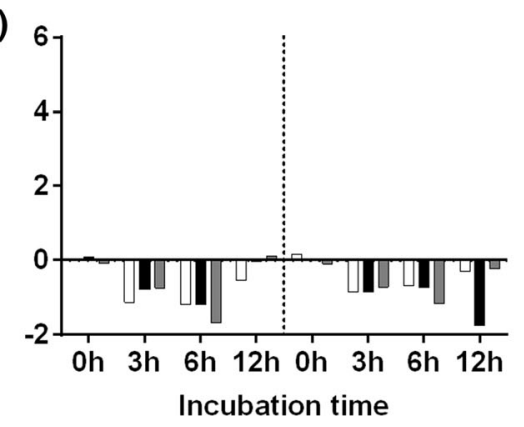

nontreated cells /

DMSO

250Treh-EP

250Treh+EP 
and MSCs activated with IFN $\gamma$ plus TNF $\alpha$. Gene expression of various immunomodulatory factors was examined: IDO1, IL10, TNFA, TSG6, IL6, and TGFBI (Fig. 5).

Expression of the main immunomodulatory gene IDO1 in ASCs was similar across all of the cryopreserved ASCs, compared to the nontreated ASCs. However, when comparing DMSO cryopreservation with $250 \mathrm{mM}$ trehalose cryopreservation, higher IDOI expression was seen, at 2.7-fold that for nonelectroporated ASCs, and 3.0-fold for electroporated ASCs (Fig. 5a). In UC-MSCs, the highest IDOI expression was for the cryopreservation in $250 \mathrm{mM}$ trehalose, which was a little higher in the electroporated UCMSCs. Compared to the DMSO cryopreservation, a 4-fold increase was seen with trehalose and no electroporation, which was increased further to 5.6fold with trehalose and electroporation (Fig. 5b).

The ILIO gene was down-regulated in all of the ASCs, except with DMSO cryopreservation, which showed an 18-fold increase (Fig. 5c). A similar pattern was seen for the UC-MSCs, where expression of ILIO was increased about 4-fold only for DMSO cryopreservation (Fig. 5d).

Expression of TNFA was almost the same across all of the ASC conditions here (Fig. 5e), while for UCMSCs, TNFA showed its highest expression in the noncryopreserved nontreated cells (Fig. 5f).

Expression of TSG6 was also up-regulated with 250 $\mathrm{mM}$ trehalose compared with DMSO cryopreservation for both cell types. For ASCs, TSG6 expression was 37.2-fold higher for the cryopreserved cells with trehalose, and 4.3-fold higher for the electroporated cells with trehalose (Fig. 5g). A similar pattern was seen for UC-MSCs, where trehalose inclusion resulted in 4.5-fold and 1.3-fold increases for nonelectroporated and electroporated cells, respectively, in comparison to the DMSO cryopreservation (Fig. 5h).

The IL6 gene was up-regulated in all of the cryopreserved cells in comparison to the nontreated cells. However, in comparison to DMSO cryopreservation, IL6 was less expressed in the electroporated cells that were cryopreserved with trehalose, as 1.6fold and 3.3-fold for ASCs and UC-MSCs, respectively (Fig. 5i, j).

Finally, for the expression of TGFB1 in both cell types, the small changes in expression seen were not biologically significant (Fig. 5k, 1).
Fig. 5 Expression of the IDOI (a, b), ILIO (c, d), TNFA (e, f), TSG6 (g, h), IL6 (i, j), and TGFB1 (k, l) immunomodulatory genes by human adipose-derived stromal cells (ASC) (a, c, e, g, i, k) and human umbilical-cord-derived mesenchymal stromal cells (UC-MSC) (b, d, f, h, j, l). Gene expression was determined before (nontreated cells: no cryopreservation, no electroporation) and after cryopreservation (CP; as indicated) with DMSO and with $250 \mathrm{mM}$ trehalose without (250Treh-EP) and with $(250 \mathrm{Treh}+\mathrm{EP})$ electroporation. The cells were activated using IFN $\gamma$ plus TNF $\alpha$. Expression data are means of triplicates, as normalized to their nonactivated counterparts. Differences between treated and nontreated samples can be considered biologically relevant for linear fold changes $\geq 4$ (i.e., $\log _{2}(R Q) \geq 2$ for the logarithmic scale). RQ, relative quantity (see Methods)

\section{Discussion}

To replace DMSO for cryopreservation of therapeutic cell products, the introduction of potential nontoxic cryoprotectants has been studied extensively. One approach has been to identify new single or combination cryoprotectants that can provide similar protective functions to DMSO, and thus inhibit ice formation and stabilize cell membranes. These substitutes can be sugars and sugar alcohols or 'antifreeze' (glycol)protein mimics. Another approach has been to develop novel technologies to replace conventional cryopreservation without DMSO involvement, as for cell encapsulation, nano-rewarming with magnetic induction heating, or intracellular sugar delivery by nanoparticle-mediated delivery or electroporation. In comparison to the other strategies, as one of the relatively simple and cost-effective methods, the use of electroporation might allow DMSO-free cell cryopreservation (Awan et al. 2020; Weng and Beauchesne 2020).

In the present study, we first wanted to determine the intracellular trehalose concentration that would suffice to protect the ASCs and UC-MSCs during cryopreservation. As can be seen here for the intracellular trehalose assessment with $250 \mathrm{mM}$ extracellular trehalose, before cryopreservation this resulted in about $10 \mathrm{mM}$ and about $40 \mathrm{mM}$ to $50 \mathrm{mM}$ intracellular trehalose in the nonelectroporated and electroporated cells, respectively. After cryopreservation, an increase to $20 \mathrm{mM}$ to $50 \mathrm{mM}$ intracellular trehalose was seen for the nonelectroporated cells, and to $50 \mathrm{mM}$ to $90 \mathrm{mM}$ for the electroporated cells. In all cases, considering the resealing of the cell membrane 


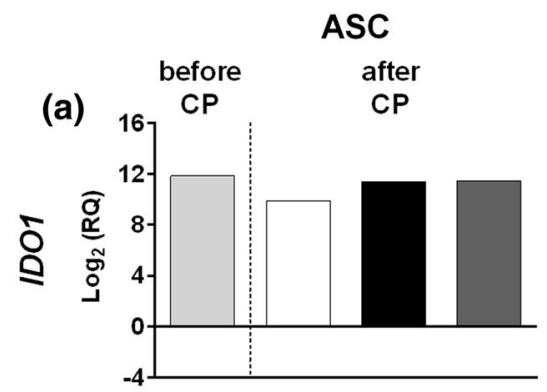

UC-MSC
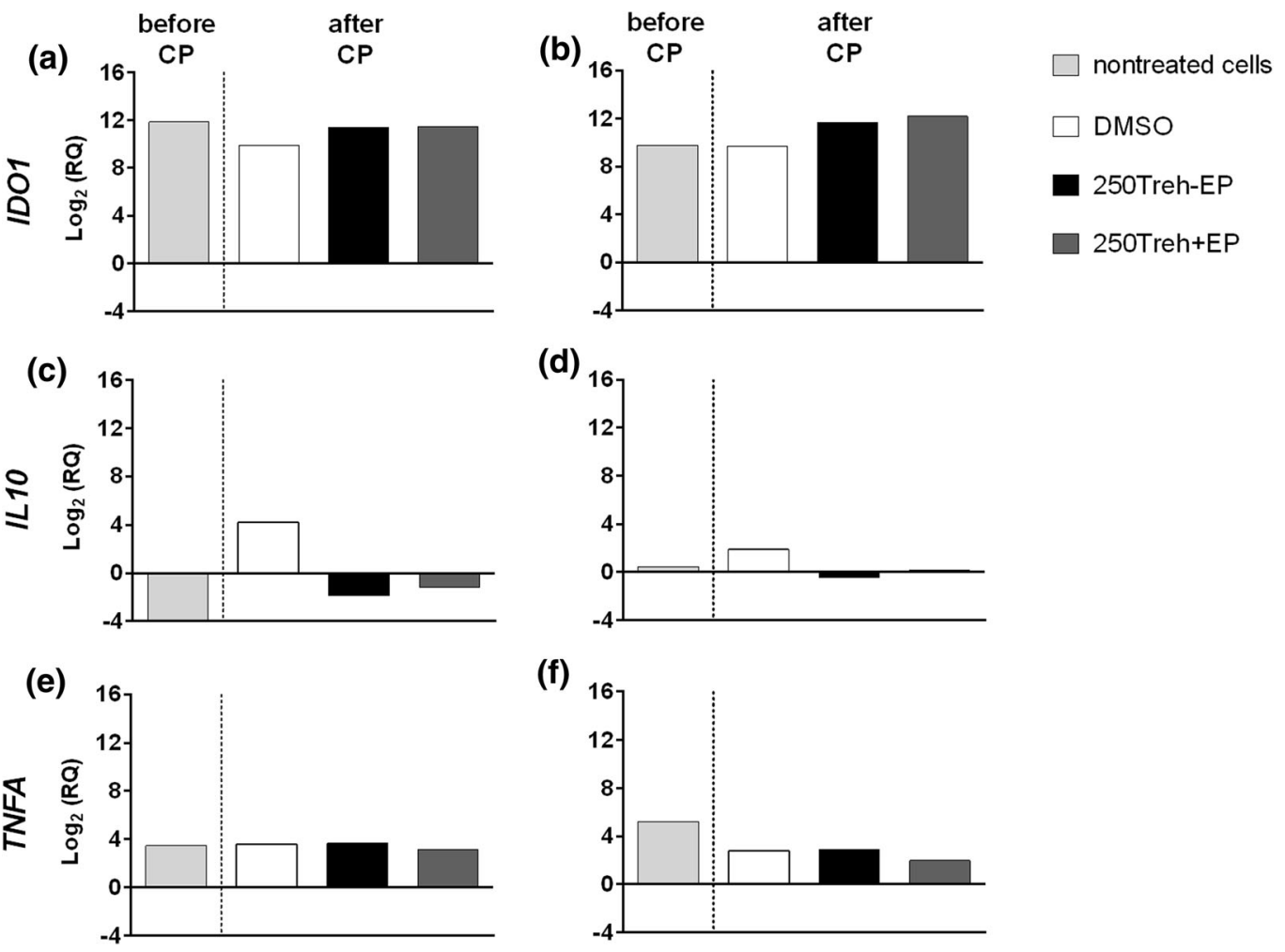

(d)

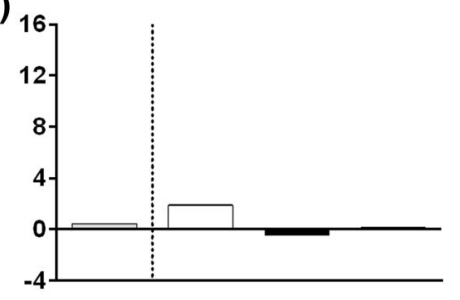

(f)

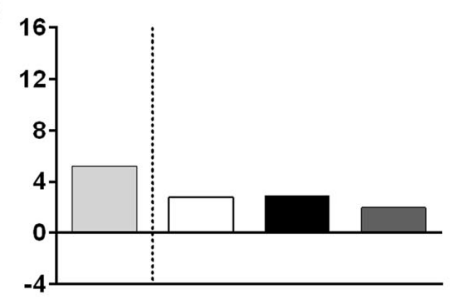

(h)

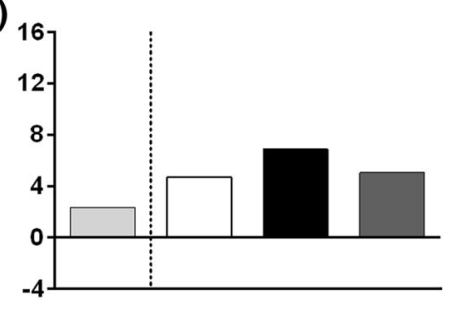

(j)

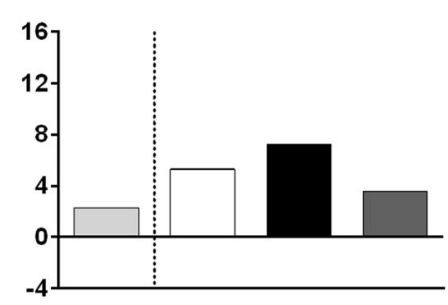

(I)

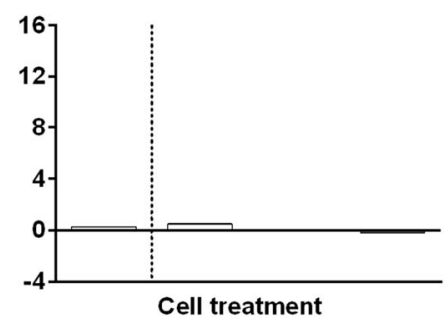


after the electroporation, some temperature dependence for trehalose uptake was observed. Kinosita and Tsong (1977), Rols et al. (1994), Saulis (1997) reported faster resealing of cell membranes after electroporation at $37{ }^{\circ} \mathrm{C}$. However, in the present study, before cryopreservation the temperature dependence for trehalose loading did not reach significance. After cryopreservation, increasing intracellular trehalose concentrations were seen for higher resealing temperatures. The highest intracellular trehalose was at $37{ }^{\circ} \mathrm{C}$ and the lowest at $4{ }^{\circ} \mathrm{C}$, for both nonelectroporated and electroporated cells. Thus, after cryopreservation, the trehalose uptake might be enhanced due to thermotropic lipid phase transition of the membranes, as has already been reported for pancreatic islets, endothelial cells, and fibroblasts (Beattie et al. 1997; Campbell and Brockbank 2012; Zhang et al. 2016). In this case, the cell membrane permeability is increased, which can occur during freezing phase as well as during thawing, and thus might allow greater influx of trehalose down its concentration gradient.

Before cryopreservation of the nonelectroporated cells, there was slightly increased trehalose uptake with increased resealing temperature for both of these cell types, which might indicate trehalose uptake by fluid-phase endocytosis. Also, greater trehalose uptake was seen for the nonelectroporated cells after cryopreservation. In fluid-phase endocytosis, the extracellular trehalose would be internalized in vesicles that are pinched off from the cell membrane. Oliver et al. (2004) also reported the loading of $20 \mathrm{mM}$ to $30 \mathrm{mM}$ trehalose into noncryopreserved MSCs by the same mechanism. Zhang et al. (2010) achieved about 14 $\mathrm{mM}$ intracellular trehalose in MSCs after $24 \mathrm{~h}$ incubation with $100 \mathrm{mM}$ trehalose. In their study, the cells were lyophilized and the recovery rates were almost $70 \%$; however, the cells remained with some significantly impaired functional characteristics. As endocytosis is temperature dependent and increases with increased temperature, higher trehalose uptake occurs at higher resealing temperatures. In the present study, the cells were exposed to trehalose for only $30 \mathrm{~min}$, while Oliver et al. (2004) and Zhang et al. (2010) incubated their cells for $24 \mathrm{~h}$. Presumably, if our cells had been exposed to trehalose for longer times, more obvious temperature dependence of this endocytosis process would have been observed.
After cryopreservation, the same phenomenon of increased trehalose uptake with increased resealing temperature for the nonelectroporated and electroporated cells was observed. Phase transition will most likely have occurred during the freezing and thawing, although not with just cooling (i.e., $30-10{ }^{\circ} \mathrm{C}$ ), at least not in any considerable way, as also observed for fibroblasts by Zhang et al. (2016). It has been reported that the membrane phase and the permeability properties are drastically altered upon ice crystal formation, which affects the permeability of the cell membranes to water and other molecules (Akhoondi et al. 2012; Zhang et al. 2016). As Zhang et al. (2016) suggested, as well as phase transition, freezinginduced uptake of membrane-impermeant molecules can be attributed to a combination of the osmotic forces and membrane imperfections induced by extracellular ice formation.

However, as already noted above (see Methods), small variations in cell size and numbers can have large effects on determination of the intracellular trehalose concentration. Thus, the data reported here as the intracellular trehalose concentrations need to be considered as estimates, rather than absolute values.

To determine the necessary extracellular trehalose concentration needed to preserve high cell viability here, the extracellular trehalose was increased to 250 $\mathrm{mM}$, as in our previous study the cell viability was not improved further at $400 \mathrm{mM}$ extracellular trehalose (Dovgan et al. 2017). As expected, the viability of the cells exposed to electroporation and/or incubation with trehalose prior to cryopreservation was not affected. However, after cryopreservation, there was strong positive correlation between the trehalose concentration and the cell viability. The cell survival in $250 \mathrm{mM}$ trehalose was comparable to that using the standard DMSO cryopreservation protocol. Surprisingly, however, survival of the cells that were only incubated and cryopreserved with trehalose (i.e., no electroporation) was only about $10 \%$ lower than that of the electroporated cells with trehalose. This discrepancy compared to our recent studies (Dovgan et al. 2017; Mutsenko et al. 2019) might originate from some small changes to the protocol that were used in the present study. Here, after the electroporation, the cells were incubated for $30 \mathrm{~min}$ to allow the membranes to reseal, in comparison to the 2 min used by Mutsenko et al. (2019). 
As previously reported, the time and temperature needed for (electro)permeabilization and membrane resealing is important (Kinosita and Tsong 1977; Rols et al. 1994; Saulis 1997; Kandušer et al. 2008). Interestingly, in comparison to DMSO, there was greater cell proliferation after cryopreservation in both the nonelectroporated (110\%) and electroporated (140\%) UC-MSCs as determined by MTT test. This MTT assay for cell proliferation is based on mitochondrial metabolic activity, and the mitochondria can become hyperactive when homeostasis is disrupted by different stress inducers. Stress-induced mitochondrial biogenesis and increased metabolic activity might thus lead to increased chemical reduction of MTT (Rai et al. 2018). Of note, we also showed here that these ASCs and UC-MSCs undergo oxidative stress due to electroporation and cryopreservation, with up-regulation of SOD2 expression. Thus, the consequent mitochondria hyperactivation might have led to higher values in the MTT assay in UC-MSCs, as indicative of this apparently higher cell proliferation. To confirm this speculation, additional experiments using multiple cell donors need to be performed.

Overall, compared to extracellular trehalose treatment alone, while the electroporation conditions used here introduced significantly greater amounts of trehalose into these MSCs, these increased intracellular concentrations of trehalose appeared to be insufficient to significantly improve cell viability. However, for both cell types, the $250 \mathrm{mM}$ extracellular trehalose (without or with electroporation) provided comparable cryoprotection to the standard $10 \%$ DMSO protocol. For the cell survival after cryopreservation, about $20 \mathrm{mM}$ to $50 \mathrm{mM}$ intracellular trehalose is sufficient, which can apparently also be achieved without electroporation. Using electroporation, $50 \mathrm{mM}$ to $90 \mathrm{mM}$ intracellular trehalose is obtained, which provides only about $10 \%$ greater cell survival after cryopreservation. However, greater trehalose uptake was achieved with the cell membrane resealing incubation at higher temperatures, rather than at low temperature (i.e., $4{ }^{\circ} \mathrm{C}$ ), which is in agreement with other studies (Kinosita and Tsong 1977; Saulis 1997).

Other methods have been used to introduce trehalose into cells, such as engineered pore-forming using $\alpha$-hemolysin (Buchanan et al. 2004), and the design of $\mathrm{pH}$-responsive nanoparticles to encapsulate the trehalose (Rao et al. 2015). In comparison to these, electroporation does not require extensive manipulation of the cell therapy product (i.e., the MSCs), which is an additional advantage (Weng and Beauchesne 2020). Also, we believe that any such cell therapy product needs to contain the highest possible numbers of viable cells when administered to the patient. Therefore, the additional $10 \%$ cell viability achieved by using electroporation in the present study although low might still represent added value for these therapeutic products.

Electroporation and cryopreservation are known stressors for mammalian cells (Forjanič et al. 2019; Liu et al. 2000). Therefore, gene expression analysis was also performed here to assess the stress responses of these MSCs, and to determine the effects on the functional immunomodulatory properties of these two cell types. Cells respond to stress in a variety of ways, which range from activation pathways that promote survival, to activation of programmed cell death (Fulda et al. 2010). Therefore, the expression of genes involved in apoptosis (BCL2), DNA damage (TP53), heat shock responses (HSPB2, HSPA1A), and oxidative stress ( $S O D 2)$ was analyzed. Here, the electroporation and cryopreservation procedures did not significantly affect the expression of BCL2 or TP53.

On the other hand, it is well established that electroporation with pulses of $0.1 \mathrm{~ms}$ to $15 \mathrm{~ms}$ duration (Bonnafous et al. 1999; Gabriel and Teissié 1994), and also nanosecond pulses (Nuccitelli et al. 2013; Pakhomova et al. 2012), can stimulate the production of reactive oxygen species (ROS) in various mammalian cell lines. Under normal conditions in cells, there is an equilibrium between pro-oxidant species and antioxidant defense mechanisms, such as the ROS-metabolizing enzymes (e.g. SOD2). Oxidative stress occurs when there is a disturbance in this balance (Fulda et al. 2010). In our approach here, we did not directly quantify the changes in ROS within cells; instead, we measured the changes in the expression of the SOD2 gene. This gene is a mitochondrial member of the iron/manganese SOD family, and it is responsible for clearing of mitochondrial ROS and for protection of cells against apoptosis and cell death (Pias et al. 2003). In the present study, electroporation resulted in increased SOD2 expression even before cryopreservation, for both of these cells types. This increase in SOD2 expression was also time dependent, and was greatest at the longest time measurement here (i.e., 12 h). After cryopreservation, 
the increase in SOD2 expression in the electroporated cells was even higher than before cryopreservation. Cryopreservation in the presence of trehalose without electroporation also strongly induced SOD2 expression. It thus appears that judging by SOD 2 expression, preservation of cells with DMSO results in less oxidative stress. However, the time courses for these changes in SOD2 expression showed opposite effects between the nonelectroporated and electroporated cells: SOD2 expression was decreased with time for the nonelectroporated cells, while it increased with time for the electroporated cells. The significance of this phenomenon on the functional properties of stromal cells has not been studied yet.

Heat shock proteins are encoded by the heat shock genes that express this family of proteins that are produced by cells in response to exposure to various stress conditions. An increase in $H S P A 1 B$ expression (which encodes a member of the HSP70 family) has already been described for electroporation of the malignant melanoma SK-MEL28 cell line (Mlakar et al. 2009). In the present study, we analyzed the expression of HSPAIA and HSPB2 (which encodes a member of the small heat-shock protein family). However, only HSPAIA expression was up-regulated, and it also differed between these two cell types. The origin of these differences between ASCs and UCMSCs for HSPA1A expression is not known at present. Although all MSCs isolated from various origins share considerable similarities in their immunological phenotypes and differentiation potential, there are biological differences in their transcriptomes and secretomes, as well for their in-vitro and in-vivo functionality (Burja et al. 2020; Grégoire et al. 2019; Hu et al. 2013).

For ASCs in particular, HSPA1A expression was already increased significantly with cryopreservation after $3 \mathrm{~h}$. Interestingly, HSPAlA expression was highest in ASCs cryopreserved with trehalose and without electroporation. ASCs electroporated in the presence of trehalose also expressed high levels of HSPA1A that increased with time. Further, the standard DMSO protocol led to biologically significant changes in HSPAIA expression in the cryopreserved ASCs. Similarly, the effects of cryopreservation using 5\% DMSO have revealed increased expression of HSP70A and HSP7OB in bone marrow-derived MSCs (François et al. 2012). As these authors suggested, the stress response induced by cryopreservation might have a temporary effect on the immunosuppressive properties of MSCs.

Most MSC-based therapies exploit their trophic, paracrine, and immunomodulatory functions for treatment of various pathological conditions; e.g., for cardiovascular diseases and autoimmune disorders (Murphy et al. 2013). If cryopreserved cell therapy products are used in the clinic, immuno-suppression by the freshly thawed cells is of great importance. However, MSCs are not spontaneously immunosuppressive, as they require activation of their immunomodulatory properties. The most important 'licensing' or activation factors are IFN $\gamma, \mathrm{TNF} \alpha$, and IL1 $\beta$ (Krampera et al. 2011; Zhang et al. 2016). Upon activation, MSCs express a variety of bioactive molecules that can immunomodulate inflammatory environments. Among the most important are IDO, TSG6, TGF $\beta$, TNF $\alpha$, IL10, IL6, and PGE2, although there are a number of others (Krampera 2011; Lee et al. 2014; Zachar et al. 2016).

In our functional bioassays, the inflammatory environment was established by activating ASCs and UC-MSCs with the combination of IFN $\gamma$ and TNF $\alpha$. Changes in gene expressions across the nonactivated and activated cells revealed the responsiveness of these cells to this inflammatory stimulus. Here, $I D O$ and TSG6 expression were the most up-regulated in all of these cells, as nontreated and cryopreserved. As a comparison only among the different cryopreservation protocols here, the DMSO protocol resulted in the lowest expression of both IDO and TSG6. The expression of the other genes examined here, except IL10, did not differ that much between the DMSO and trehalose cryopreserved cells. This higher expression of IDO and TSG6 for the trehalose cryopreserved cells (without or with electroporation) is an encouraging result. To date, MSCs cryopreserved with DMSO have shown impaired immunomodulatory properties, which will presumably affect the therapeutic activities of such cryopreserved cell products (François et al. 2012; Moll et al. 2014). In the present study, despite elevated oxidative stress and HSPAIA expression, for cryopreservation in trehalose, the expression of IDO, TSG6 and the other genes was not affected. When MSCs are administered systemically to patients for immunomodulatory purposes, their mode of action has been described as 'hit and run' (Erkers et al. 2015): they act by expressing various immunomodulatory molecules, and they are cleared out from the body 
within $48 \mathrm{~h}$. In our opinion, the elevated expression levels of these stress genes do not affect the immunomodulatory gene expression, as seen in our study. However, these data are worth further exploration using additional functional bioassays, such as mixed lymphocyte reactions, secretome analysis, and surface-marker expression analysis (de Wolf et al. 2017; Galipeau et al. 2016).

Despite a number of shortcomings of the present study (single tissue donors, methods for assessing viability, nonoptimized electroporation conditions), these data contribute to the understanding of cryopreservation using sugars, and opens new possibilities for xeno-free and DMSO-free cryopreservation of MSC-based medicines.

\section{Conclusions}

The present study has shown the feasibility for efficient cryopreservation of ASCs and UC-MSCs using trehalose, with maintained post-cryopreservation immune responsiveness. While inclusion of the electroporation conditions used here provided loading into the cells of relatively high concentrations of trehalose (maximum, $87 \mathrm{mM}$ ), this did not result in significantly increased cell viability (maximum increase, $10 \%$ ) compared to incubation in trehalose without electroporation. The stress induced by the electroporation and/or cryopreservation increased the expression of the SOD2 and HSPA1A genes; however, expression of the main immunosuppressive genes IDOI and TSG6 was even higher with trehalose than in DMSO cryopreserved cells.

Acknowledgements The authors thank Dr. Chris Berrie for scientific English editing of the manuscript.

Funding This study was supported by the Slovenian Research Agency through the Research Programme 'ElectroporationBased Technologies and Treatments' (P2-0249), and by the Infrastructure Programme: Network of research infrastructure centres at the University of Ljubljana (IP-0510).

\section{Declarations}

Conflict of interest The authors declare that they have no conflicts of interest.

Ethical approval Human adipose tissue was obtained with informed consent and in accordance with the ethical guidelines of the National Medical Ethics Committee (code 21/09/07).
Human mesenchymal stromal cells from umbilical cord were obtained with informed consent and in accordance with the ethical guidelines of the National Medical Ethics Committee (code 136/02/12).

\section{References}

Akhoondi M, Oldenhof H, Sieme H, Wolkers WF (2012) Freezing-induced cellular and membrane dehydration in the presence of cryoprotective agents. Mol Membr Biol 29:197-206. https://doi.org/10.3109/09687688.2012. 699106

Akkök ÇA, Liseth K, Nesthus I, Løkeland T, Tefre K, Bruserud O, Abrahamsen JF (2008) Autologous peripheral blood progenitor cells cryopreserved with $5 \%$ and $10 \%$ dimethyl sulfoxide alone give comparable hematopoietic reconstitution after transplantation. Transfusion 48:877-883. https://doi.org/10.1111/j.1537-2995.2008.01648.x

Al-Saqi SH, Saliem M, Quezada HC, Ekblad A, Jonasson AF, Hovatta O, Götherström C (2015) Defined serum- and xeno-free cryopreservation of mesenchymal stem cells. Cell Tissue Bank 16:181-193. https://doi.org/10.1007/ s10561-014-9463-8

Aragona P, Colosi P, Rania L, Colosi F, Pisani A, Puzzolo D, Micali A (2014) Protective effects of trehalose on the corneal epithelial cells. Sci World J 2014:717835. https:// doi.org/10.1155/2014/717835

Awan M, Buriak I, Fleck R, Fuller B, Goltsev A, Kerby J, Lowdell M, Mericka P, Petrenko A, Petrenko Y, Rogulska O, Stolzing A, Stacey GN (2020) Dimethyl sulfoxide: a central player since the dawn of cryobiology, is efficacy balanced by toxicity? Regen Med 15:1463-1491. https:// doi.org/10.2217/rme-2019-0145

Bakken A, Bruserud O, Abrahamsen J (2003) No differences in colony formation of peripheral blood stem cells frozen with $5 \%$ or $10 \%$ dimethyl sulfoxide. J Hematother Stem Cell Res 12:351-358. https://doi.org/10.1089/ 152581603322023089

Baust JM, Campbell LH, Harbell JW (2017) Best practices for cryopreserving, thawing, recovering, and assessing cells. In Vitro Cell Dev Biol Anim 53:855-871. https://doi.org/ 10.1007/s11626-017-0201-y

Beattie GM, Crowe JH, Lopez AD, Crulli V, Ricordi C, Hayek A (1997) Trehalose: a cryoprotectant that enhances recovery and preserves function of human pancreatic islets after long-term storage. Diabetes 46:519-523. https://doi. org/10.2337/diab.46.3.519

Bonnafous P, Vernhes M, Teissié J, Gabriel B (1999) The generation of reactive-oxygen species associated with long-lasting pulse-induced electropermeabilisation of mammalian cells is based on a non-destructive alteration of the plasma membrane. Biochim Biophys Acta 1461:123-134. https://doi.org/10.1016/s00052736(99)00154-6

Brockbank KGM, Campbell LH, Greene ED, Brockbank MCG, Duman JG (2010) Lessons from nature for preservation of mammalian cells, tissues, and organs. In Vitro Cell Dev Biol Anim 47:210-217. https://doi.org/10.1007/s11626010-9383-2 
Buchanan SS, Gross SA, Acker JP, Toner M, Carpenter JF, Pyatt DW (2004) Cryopreservation of stem cells using trehalose: evaluation of the method using a human hematopoietic cell line. Stem Cell Dev 13:295-305. https://doi.org/10.1089/ 154732804323099226

Burja B, Barlič A, Erman A, Mrak-Poljšak K, Tomšič M, SodinSemrl S, Lakota K (2020) Human mesenchymal stromal cells from different tissues exhibit unique responses to different inflammatory stimuli. Curr Res Transl Med 68:217-224. https://doi.org/10.1016/j.retram.2020.05.006

Campbell LH, Brockbank KG (2012) Culturing with trehalose produces viable endothelial cells after cryopreservation. Cryobiology 64:240-244. https://doi.org/10.1016/j. cryobiol.2012.02.006

Chiambaretta F, Doan S, Labetoulle M, Rocher N, Fekih LE, Messaoud R, Khairallah M, Baudouin C, HA-trehalose Study Group (2017) A randomized, controlled study of the efficacy and safety of a new eyedrop formulation for moderate to severe dry eye syndrome. Eur J Ophthalmol 27:1-9. https://doi.org/10.5301/ejo.5000836

Crowe JH, Crowe LM, Wolkers WF, Oliver AE, Ma X, Auh JH, Tang M, Zhu S, Norris J, Tablin F (2005) Stabilization of dry mammalian cells: lessons from nature. Integr Comp Biol 45:810-820. https://doi.org/10.1093/icb/45.5.810

Crowe JH, Crowe LM (2000) Preservation of mammalian cells learning Nature's tricks. Nat Biotechnol 18:145-146. https://doi.org/10.1038/72580

de Luca M, Aiuti A, Cossu G, Parmar M, Pellegrini G, Robey PG (2019) Advances in stem cell research and therapeutic development. Nat Cell Biol 21:801-811. https://doi.org/10. 1038/s41556-019-0344-z

de Wolf C, van de Bovenkamp M, Hoefnagel M (2017) Regulatory perspective on in-vitro potency assays for human mesenchymal stromal cells used in immunotherapy. Cytotherapy 19:784-797. https://doi.org/10.1016/j.jcyt. 2017.03.076

Dovgan B, Barlič A, Knežević M, Miklavčič D (2017) Cryopreservation of human adipose-derived stem cells in combination with trehalose and reversible electroporation. J Membr Biol 250:1-9. https://doi.org/10.1007/s00232016-9916-Z

Dulugiac M, Moldovan L, Zarnescu O (2015) Comparative studies of mesenchymal stem cells derived from different cord tissue compartments - the influence of cryopreservation and growth media. Placenta 36:1192-1203. https://doi. org/10.1016/j.placenta.2015.08.011

Dymek K, Dejmek P, Galindo FG (2014) Influence of pulsed electric field protocols on the reversible permeabilization of rucola leaves. Food Bioprocess Tech 7:761-773. https:// doi.org/10.1007/s11947-013-1067-y

Erkers T, Kaipe H, Nava S, Molldén P, Gustafsson B, Axelsson R, Ringdén O (2015) Treatment of severe chronic graftversus-host disease with decidual stromal cells and tracing with ${ }^{111}$ Indium radiolabelling. Stem Cells Dev 24:253-263. https://doi.org/10.1089/scd.2014.0265

Eroglu A, Bailey SE, Toner M, Toth TL (2009) Successful cryopreservation of mouse oocytes by using low concentrations of trehalose and dimethyl sulfoxide. Biol Reprod 80:70-78. https://doi.org/10.1095/biolreprod.108.070383

Eroglu A, Russo MJ, Bieganski R, Fowler A, Cheley S, Bayley $H$, Toner M (2000) Intracellular trehalose improves the survival of cryopreserved mammalian cells. Nat Biotechnol 18:163-167. https://doi.org/10.1038/72608

Forjanič T, Markelc B, Marčan M, Bellard E, Couillaud F, Golzio M, Miklavčič D (2019) Electroporation-induced stress response and its effect on gene electrotransfer efficacy: in-vivo imaging and numerical modeling. IEEE Trans Biomed Eng 66:2671-2683. https://doi.org/10.1109/ TBME.2019.2894659

François M, Copland IB, Yuan S, Romieu-Mourez R, Waller EK, Galipeau J (2012) Cryopreserved mesenchymal stromal cells display impaired immunosuppressive properties as a result of heat-shock response and impaired interferon$\gamma$ licensing. Cytotherapy 14:147-152. https://doi.org/10. 3109/14653249.2011.623691

Fry LJ, Querol S, Gomez SG, McArdle S, Rees R, Madrigal JA (2015) Assessing the toxic effects of DMSO on cord blood to determine exposure time limits and the optimum concentration for cryopreservation. Vox Sang 109:181-190. https://doi.org/10.1111/vox.12267

Fulda S, Gorman AM, Hori O, Samali A (2010) Cellular stress responses: cell survival and cell death. Int J Cell Biol. https://doi.org/10.1155/2010/214074

Gabriel B, Teissié J (1994) Generation of reactive-oxygen species induced by electropermeabilization of Chinese hamster ovary cells and their consequence on cell viability. Eur J Biochem 223:25-33. https://doi.org/10.1111/j.14321033.1994.tb18962.x

Galipeau J, Krampera M, Barrett J, Dazzi F, Deans RJ, DeBruijn J, Dominici M, Fibbe WE, Gee AP, Gimble JM, Hematti P, Koh MB, LeBlanc K, Martin I, McNiece IK, Mendicino M, Oh S, Ortiz L, Phinney DG, Planat V, Shi Y, Stroncek DF, Viswanathan S, Weiss DJ, Sensebe L (2016) International Society for Cellular Therapy perspective on immune functional assays for mesenchymal stromal cells as potency release criterion for advanced phase clinical trials. Cytotherapy 18:151-159. https://doi.org/10.1016/j.jcyt. 2015.11.008

Ge J, Guo L, Wang S, Zhang Y, Cai T, Zhao RC, Wu Y (2014) The size of mesenchymal stem cells is a significant cause of vascular obstructions and stroke. Stem Cell Rev Rep 10:295-303. https://doi.org/10.1007/s12015-013-9492-x

Geboers B, Scheffer HJ, Graybill PM, Ruarus AH, Nieuwenhuizen S, Puijk RS, van den Tol PM, Davalos RV, Rubinsky B, de Gruijl TD, Miklavčič D, Meijerink MR (2020) High-voltage electrical pulses in oncology: irreversible electroporation, electrochemotherapy, gene electrotransfer, electrofusion, and electroimmunotherapy. Radiology 295:254-272. https://doi.org/10.1148/radiol. 2020192190

Golchin A, Seyedjafari E, Ardeshirylajim A (2020) Mesenchymal stem cell therapy for COVID-19: present or future. Stem Cell Rev Rep 16:427-433. https://doi.org/10. 1007/s12015-020-09973-w

Grégoire C, Ritacco C, Hannon M, Seidel L, Delens L, Belle L, Dubois S, Vériter S, Lechanteur C, Briquet A, Servais S, Ehx G, Beguin Y, Baron F (2019) Comparison of mesenchymal stromal cells from different origins for the treatment of graft-vs.-host disease in a humanized mouse model. Front Immunol 10:619. https://doi.org/10.3389/ fimmu.2019.00619 
Halle P, Tournilhac O, Knopinska-Posluszny W, Kanold J, Gembara P, Boiret N, Rapatel C, Berger M, Travade P, Angielski S, Bonhomme J, Deméocq F (2001) Uncontrolled-rate freezing and storage at $-80{ }^{\circ} \mathrm{C}$, with only $3.5 \%$ DMSO in cryoprotective solution for 109 autologous peripheral blood progenitor cell transplantations. Transfusion 41:667-673. https://doi.org/10.1046/j.1537-2995. 2001.41050667.x

Hornberger K, Yu G, McKenna D, Hubel A (2019) Cryopreservation of hematopoietic stem cells: emerging assays, cryoprotectant agents, and technology to improve outcomes. Transfus Med Hemother 46:188-196. https://doi. org/10.1159/000496068

Hu L, Hu J, Zhao J, Liu J, Ouyang W, Yang C, Gong N, Du L, Khanal A, Chen L (2013) Side-by-side comparison of the biological characteristics of human umbilical cord and adipose tissue-derived mesenchymal stem cells. Biomed Res Int 2013:438243. https://doi.org/10.1155/2013/ 438243

Ikebe C, Suzuki K (2014) Mesenchymal stem cells for regenerative therapy: optimization of cell preparation protocols. Biomed Res Int. https://doi.org/10.1155/2014/951512

Kabat M, Bobkov I, Kumar S, Grumet M (2020) Trends in mesenchymal stem cell clinical trials 2004-2018: is efficacy optimal in a narrow dose range? Stem Cells Transl Med 9:17-27. https://doi.org/10.1002/sctm.19-0202

Kandušer M, Šentjurc M, Miklavčič D (2008) The temperature effect during pulse application on cell membrane fluidity and permeabilization. Bioelectrochemistry 74:52-57. https://doi.org/10.1016/j.bioelechem.2008.04.012

Kinosita K Jr, Tsong TY (1977) Formation and resealing of pores of controlled sizes in human erythrocyte membrane. Nature 5619:438-441. https://doi.org/10.1038/268438a0

Kotnik T, Kramar P, Pucihar G, Miklavčič D, Tarek M (2012) Cell membrane electroporation-Part 1: the phenomenon. IEEE Electr Insul M 28:14-23. https://doi.org/10.1109/ MEI.2012.6268438

Kotnik T, Rems L, Tarek M, Miklavčič D (2019) Membrane electroporation and electropermeabilization: mechanisms and models. Annu Rev Biophys 48:63-91. https://doi.org/ 10.1146/annurev-biophys-052118-115451

Krampera M (2011) Mesenchymal stromal cell 'licensing': a multistep process. Leukemia 25:14081414. https://doi.org/ 10.1038/leu.2011.108

Kui L, Chan GC, Lee PP (2017) TSG-6 Downregulates IFN- $\alpha$ and TNF- $\alpha$ expression by suppressing IRF7 phosphorylation in human plasmacytoid dendritic cells. Mediators Inflamm 7462945. https://doi.org/10.1155/2017/7462945

Laroche V, McKenna DH, Moroff G, Schierman T, Kadidlo D, McCullough J (2005) Cell loss and recovery in umbilical cord blood processing: a comparison of post-thaw and postwash samples. Transfusion 45:1909-1916. https://doi.org/ 10.1111/j.1537-2995.2005.00638.x

Larson DJ, Middle L, Vu H, Zhang W, Serianni AS, Duman J, Barnes BM (2014) Wood frog adaptations to overwintering in Alaska: new limits to freezing tolerance. J Exp Biol 217:2193-2200. https://doi.org/10.1242/jeb.101931

Lee RH, Yu JM, Foskett AM, Peltier G, Reneau JC, Bazhanov N, Oh JY, Prockop DJ (2014) TSG-6 as a biomarker to predict efficacy of human mesenchymal stem/progenitor cells (hMSCs) in modulating sterile inflammation in vivo.
Proc Natl Acad Sci USA 111:16766-16771. https://doi. org/10.1073/pnas.1416121111

Liu K, Yang Y, Mansbridge J (2000) Comparison of the stress response to cryopreservation in monolayer and three-dimensional human fibroblast cultures: stress proteins, MAP kinases, and growth factor gene expression. Tissue Eng 5:539-554. https://doi.org/10.1089/107632700750022189

Marquez-Curtis LA, Janowska-Wieczorek A, McGann LE, Elliott JA (2015) Mesenchymal stromal cells derived from various tissues: biological, clinical and cryopreservation aspects. Cryobiology 71:181-197. https://doi.org/10.1016/ j.cryobiol.2015.07.003

Mitchell R, Wagner JE, Brunstein CG, Cao Q, McKenna DH, Lund TC, Verneris MR (2015) Impact of long-term cryopreservation on single umbilical cord blood transplantation outcomes. Biol Blood Marrow Transpl 21:50-54. https://doi.org/10.1016/j.bbmt.2014.09.002

Miyagi-Shiohira C, Kobayashi N, Saitoh I, Watanabe M, Noguchi Y, Matsushita M, Noguchi H (2016) Evaluation of serum-free, xeno-free cryopreservation solutions for human adipose-derived mesenchymal stem cells. Cell Med 9:15-20. https://doi.org/10.3727/215517916X693122

Mlakar V, Todorovič V, Črmažar M, Glavač D, Serša G (2009) Electric pulses used in electrochemotherapy and electrogene therapy do not significantly change the expression profile of genes involved in the development of cancer in malignant melanoma cells. BMC Cancer 9:299. https://doi. org/10.1186/1471-2407-9-299

Moll G, Alm JJ, Davies LC, von Bahr L, Heldring N, StenbeckFunke L, Hamad OA, Hinsch R, Ignatowicz L, Locke M, Lönnies H, Lambris JD, Teramura Y, Nilsson-Ekdahl K, Nilsson B, Le Blanc K (2014) Do cryopreserved mesenchymal stromal cells display impaired immunomodulatory and therapeutic properties? Stem Cells 32:2430-2442. https://doi.org/10.1002/stem.1729

Mosmann T (1983) Rapid colorimetric assay for cellular growth and survival: application to proliferation and cytotoxicity assays. J Immunol Methods 65:55-63. https://doi.org/10. 1016/0022-1759(83)90303-4

Murphy MB, Moncivais K, Caplan AI (2013) Mesenchymal stem cells: environmentally responsive therapeutics for regenerative medicine. Exp Mol Med 45:e54. https://doi. org/10.1038/emm.2013.94

Mutsenko V, Barlič A, Pezić T, Dermol-Černe J, Dovgan B, Sydykov B, Wolkers WF, Katkov II, Glasmacher B, Miklavčič D, Gryshkov O (2019) Me2SO- and serum-free cryopreservation of human umbilical cord mesenchymal stem cells using electroporation-assisted delivery of sugars. Cryobiology 91:104-114. https://doi.org/10.1016/j. cryobiol.2019.10.002

Nuccitelli R, Lui K, Kreis M, Athos B, Nuccitelli P (2013) Nanosecond pulsed electric field stimulation of reactive oxygen species in human pancreatic cancer cells is $\mathrm{Ca}^{2+}$ dependent. Biochem Biophys Res Commun 435:580-585. https://doi.org/10.1016/j.bbrc.2013.05.014

Oliver AE, Jamil K, Crowe JH, Tablin F (2004) Loading human mesenchymal stem cells with trehalose by fluid-phase endocytosis. Cell Preserv Technol 2:35-49. https://doi.org/ 10.1089/153834404322708745

Pakhomova ON, Khorokhorina VA, Bowman AM, RodaiteRiševičiene R, Saulis G, Xiao S, Pakhomov AG (2012) 
Oxidative effects of nanosecond pulsed electric field exposure in cells and cell-free media. Arch Biochem Biophys 527:55-64. https://doi.org/10.1016/j.abb.2012.08. 004

Patist A, Zoerb H (2005) Preservation mechanisms of trehalose in food and biosystems. Colloids Surf B. https://doi.org/10. 1016/j.colsurfb.2004.05.003

Pias EK, Ekshyyan OY, Rhoads CA, Fuseler J, Harrison L, Aw TY (2003) Differential effects of superoxide dismutase isoform expression on hydroperoxide-induced apoptosis in PC-12 cells. J Biol Chem 278:13294-13301. https://doi. org/10.1074/jbc.M208670200

Pilbauerová N, Suchánek J (2018) Cryopreservation of dental stem cells. Acta Med 61:1-7. https://doi.org/10.14712/ 18059694.2018.16

Pirjali T, Azarpira N, Ayatollahi M, Aghdaie MH, Geramizadeh B, Talai T (2013) Isolation and characterization of human mesenchymal stem cells derived from human umbilical cord Wharton's jelly and amniotic membrane. Int J Organ Transpl Med 4:111116

Rai Y, Pathak R, Kumari N, Sah DK, Pandey S, Kalra N, Soni R, Dwarakanath BS, Bhatt AN (2018) Mitochondrial biogenesis and metabolic hyperactivation limits the application of MTT assay in the estimation of radiation induced growth inhibition. Sci Rep 1:1531. https://doi.org/10.1038/ s41598-018-19930-w

Ramos TV, Mathew AJ, Thompson ML, Ehrhardt RO (2014) Standardized cryopreservation of human primary cells. Curr Protoc Cell Biol 64:1-8. https://doi.org/10.1002/ 0471143030.cba03is64

Rao W, Huang H, Wang H, Zhao S, Dumbleton J, Zhao G, He X (2015) Nanoparticle-mediated intracellular delivery enables cryopreservation of human adipose-derived stem cells using trehalose as the sole cryoprotectant. ACS Appl Mater Interfaces 7:5017-5028. https://doi.org/10.1021/ acsami.5b00655

Rems L, Miklavčič D (2016) Tutorial: electroporation of cells in complex materials and tissue. J App Phys 119:201101. https://doi.org/10.1063/1.4949264

Rols MP, Delteil C, Serin G, Teissié J (1994) Temperature effects on electrotransfection of mammalian cells. Nucleic Acids Res 22:540. https://doi.org/10.1093/nar/22.3.540

Roth TL, Puig-Saus C, Yu R, Shifrut E, Carnevale J, Li PJ, Hiatt J, Saco J, Krystofinski P, Li H, Tobin V, Nguyen DN, Lee MR, Putnam AL, Ferris AL, Chen JW, Schickel JN, Pellerin L, Carmody D, Alkorta-Aranburu G, Del Gaudio D, Matsumoto H, Morell M, Mao Y, Cho M, Quadros RM, Gurumurthy CB, Smith B, Haugwitz M, Hughes SH, Weissman JS, Schumann K, Esensten JH, May AP, Ashworth A, Kupfer GM, Greeley SAW, Bacchetta R, Meffre E, Roncarolo MG, Romberg N, Herold KC, Ribas A, Leonetti MD, Marson A (2018) Reprogramming human T cell function and specificity with non-viral genome targeting. Nature 559:405-409. https://doi.org/10.1038/ s41586-018-0326-5

Saulis G (1997) Pore disappearance in a cell after electroporation: theoretical simulation and comparison with experiments. Biophys J 3:1299-1309. https://doi.org/10. 1016/S0006-3495(97)78163-3

Shayanfan S, Chauhan O, Toepfl S, Heinz V (2013) The interaction of pulsed electric fields and texturizing-antifreezing agents in quality retention of defrosted potato strips. Int $\mathbf{J}$ Food Sci Technol 48:12891295. https://doi.org/10.1111/ ijfs. 12089

Shirakashi R, Köstner CM, Müller KJ, Kürschner M, Zimmermann U, Sukhorukov VL (2002) Intracellular delivery of trehalose into mammalian cells by electropermeabilization. J Membr Biol 189:45-54. https://doi.org/10.1007/ s00232-002-1003-y

Shu Z, Heimfeld S, Gao D (2014) Hematopoietic SCT with cryopreserved grafts: adverse reactions after transplantation and cryoprotectant removal before infusion. Bone Marrow Transpl 49:469-476. https://doi.org/10.1038/bmt. 2013.152

Stewart S, He X (2019) Intracellular delivery of trehalose for cell banking. Langmuir 35:7414-7422. https://doi.org/10. 1021/acs.langmuir.8b02015

Vandesompele J, De Preter K, Pattyn F, Poppe B, Van Roy N, De Paepe A, Speleman F (2002) Accurate normalization of real-time quantitative RT-PCR data by geometric averaging of multiple internal control genes. Genome Biol 3:RESEARCH0034. https://doi.org/10.1186/gb-2002-3-7research0034

Wang HY, Lun ZR, Lu SS (2011) Cryopreservation of umbilical cord blood-derived mesenchymal stem cells without dimethyl sulfoxide. Cryo Lett 32:81-88

Weng L, Beauchesne PR (2020) Dimethyl sulfoxide-free cryopreservation for cell therapy: a review. Cryobiology 94:9-17. https://doi.org/10.1016/j.cryobiol.2020.03.012

Wolkers WF, Walker NJ, Tablin F, Crowe JH (2001) Human platelets loaded with trehalose survive freeze-drying. Cryobiology 42:79-87. https://doi.org/10.1006/cryo.2001. 2306

Yong KW, Pingguan-Murphy B, Xu F, Abas WA, Choi JR, Omar SZ, Azmi MA, Chua KH, Wan Safwani WK (2015) Phenotypic and functional characterization of long-term cryopreserved human adipose-derived stem cells. Sci Rep 5:9596. https://doi.org/10.1038/srep09596

Zachar L, Bačenková D, Rosocha J (2016) Activation, homing, and role of the mesenchymal stem cells in the inflammatory environment. J Inflamm Res 9:231-240. https://doi.org/10. 2147/JIR.S121994

Zhang M, Oldenhof H, Sieme H, Wolkers WF (2016) Freezinginduced uptake of trehalose into mammalian cells facilitates cryopreservation. Biochim Biophys Acta 1858:1400-1409. https://doi.org/10.1016/j.bbamem.2016. 03.020

Zhang SZ, Qian H, Wang Z, Fan JL, Zhou Q, Chen GM, Li R, Fu S, Sun J (2010) Preliminary study on the freeze-drying of human bone marrow-derived mesenchymal stem cells. J Zhejiang Univ Sci B 11:889-894. https://doi.org/10. 1631/jzus.B1000184 
Zhou X, Yuan J, Liu J, Liu B (2010) Loading trehalose into red blood cells by electroporation and its application in freezedrying. Cryo Lett 31:147-156

Zuk PA, Zhu M, Mizuno H, Huang J, Futrell JW, Katz AJ, Benhaim P, Lorenz HP, Hedrick MH (2001) Multilineage cells from human adipose tissue: implications for cell- based therapies. Tissue Eng 7:211-228. https://doi.org/10. 1089/107632701300062859

Publisher's note Springer Nature remains neutral with regard to jurisdictional claims in published maps and institutional affiliations. 